\title{
Palaeoproterozoic banded iron formation- hosted high-grade hematite iron ore deposits of the Transvaal Supergroup, South Africa
}

\author{
Albertus J. B. Smith ${ }^{1,2^{*}}$ and Nicolas J Beukes ${ }^{1,2}$ \\ ${ }^{1}$ DST-NRF Centre of Excellence for Integrated Mineral and Energy Resource Analysis, Department of Geology, University of Johannesburg, \\ Auckland Park, 2006, South Africa *Corresponding author E-mail: bertuss@uj.ac.za \\ ${ }^{2}$ Palaeoproterozoic Mineralisation Research Group, Department of Geology, University of Johannesburg, Auckland Park, 2006, South Africa
}

DOI: 10.18814/epiiugs/2016/v39i2/95778

Banded iron formation-hosted high-grade (>60 weight percent (wt\%) iron ( $\mathrm{Fe})$ ) hematite ore deposits make up the bulk of the world's iron ore production and reserves. They developed mainly through supergene and/or hydrothermal leaching of silica from the iron formation host rock under oxidizing conditions. Early Palaeoproterozoic iron formations of the Transvaal Supergroup host several such high-grade hematite ore deposits. The largest ones are developed in the Asbesheuwels Subgroup iron formation on the Maremane Dome, between Sishen and Postmasburg in the Northern Cape Province of South Africa. These deposits currently produce virtually all of South Africa's annual supply of about 78 million tonnes (Mt) of high-grade hematite ore, to the local and export market from the Sishen, Khumani, Beeshoek and Kolomela Mines. These represent ancient supergene deposits that formed along the approximately 2.2 to 2.0 Ga unconformity at the base of the Gamagaral Mapedi red bed succession of the Keis (formerly Kheis) Supergroup. Smaller ancient supergene deposits are also developed along the same unconformity such as where it intersects the Rooinekke Iron Formation of the Koegas Subgroup at the Rooinekke Iron Ore Mine to the south of the Maremane Dome and the intersection of the Hotazel Iron Formation of the Voëlwater Subgroup of the Transvaal Supergroup, in the Kalahari Manganese Field to the north of the dome. The supergene ores occur in four types, namely laminated, massive, brecciated and conglomeratic ores, the latter forming part of the Gamagara/Mapedi red bed succession. With the exception of the ore at Rooinekke, which is manganiferous, the supergene ores are of high grade
(>60 wt\%) and they also have low silica and phosphorous contents. Normalized rare earth elements, in contrast to the banded iron formation protolith, show light rare earth element depletion and the oxygen isotopes are slightly depleted to slightly enriched in ${ }^{18} \mathrm{O}$.

Hydrothermally enriched deposits include: Thabazimbi, situated in the Penge Iron Formation of the Transvaal outcrop area of the Transvaal Supergroup in the metamorphic aureole of the Bushveld Complex; and the Bovenzeekoebaart and magmatic hydrothermal Nauga East deposit, both located in the Kuruman Iron Formation of the Asbesheuwels Subgroup, along the southern extremity of the Griqualand West outcrop area of the Transvaal Supergroup. These hydrothermal iron ores are all developed at the bottom contact between the host iron formation and underlying carbonaceous shale that marks the transition into the MalmaniCampbellrand carbonate platform succession below. In some instances this contact is faulted. The ore grades upwards into oxidized iron formation, with isolated lenses sometimes developed at higher stratigraphic levels. Fault systems intersect the iron formations and the mineralisation is concentrated between mafic sills, higher up in the iron formations and the bottom shale contact. At Nauga East, mineralisation is developed in contact with a steeply dipping zoned syenite-carbonatite dyke. The hydrothermal ores are of high grade ( $>60 \mathrm{wt} \%)$, but can have higher phosphorous contents of up to $0.25 \mathrm{wt} \%$. Normalized rare earth elements are enriched but similar to that of the host iron formations and the oxygen isotopes are generally depleted in ${ }^{18} \mathrm{O}$.

The mining of iron ore in South Africa dates from 
between 800 and $1200 A D$, with modern exploration and mining starting from 1916. The first production of high-grade banded iron formation-hosted ore commenced in 1931 from the Maremane Dome and Thabazimbi. The first truly world class iron ore mine in South Africa, Sishen, was opened in 1953 and still operates today. The deposits at Khumani and Welgevonden have gone into production as recently as 2008 and 2011 respectively. Current estimates place the life of mine of the larger deposits at between 15 and 40 years.

\section{Introduction}

Banded iron formation-hosted high-grade hematite ore deposits have, for many decades, provided by far the bulk of all iron ore mined annually ( 3.1 Bt total global iron ore mined in 2014; USGS, 2015) in the world and continue to do so. Banded iron formations (BIFs) are chemical sedimentary rocks that contain an anomalous amount of iron as iron-rich oxides, -carbonates and -silicates, along with mostly chert and they are commonly laminated or banded (James, 1954; Trendall, 1983; Klein, 2005). BIFs themselves are not of great economic significance due to their relatively low iron and high silica contents ( $\sim 3 \mathrm{wt} \%$ iron-oxide $\left[\mathrm{Fe}_{2} \mathrm{O}_{3}\right]$ and $\sim 47 \mathrm{wt} \%$ silicon-dioxide $\left[\mathrm{SiO}_{2}\right]$ on average; Gutzmer et al., 2008) when compared to the economically exploitable BIF-hosted high-grade iron ores (typically more than $60 \mathrm{wt} \% \mathrm{Fe}$ and only minor silica contents; Hagemann et al., 2008). An epigenetic process is therefore required to enrich the iron content through the removal of silica. The most common modes of enrichment through epigenetic fluid-rock interactions in BIFs are considered to be supergene, hydrothermal, or supergene-modified hydrothermal in nature (i.e. genetic types; Beukes et al., 2003). Wellknown examples of hydrothermally enriched BIF-hosted iron ores include Mount Tom Price in Western Australia and Thabazimbi in South Africa. Supergene enriched examples include the ores of the Maremane Dome in South Africa and the Urucum district in Brazil. Supergene modified hydrothermal ores include the Sandur schist belt in India and the Carajas district in Brazil (Beukes, et al., 2003; Gutzmer et al., 2008).

South Africa has several high grade BIF-hosted iron ore deposits that all occur within the Griqualand West and Transvaal areas of the Neoarchaean to Palaeoproterozoic ( 2.6-2.2 Ga; Eriksson et al., 2006) Transvaal Supergroup (Fig. 1). The largest and best known examples are hosted by the BIFs of the Asbesheuwels Subgroup of the Ghaap Group (Griqualand West area) and Penge Iron Formation of the Chuniespoort Group (Transvaal area; Fig.1). However, high-grade iron ore also occurs in the BIF of the Koegas Subgroup and the Hotazel Formation of the Postmasburg Group in Griqualand West (Cairncross and Beukes, 2013). Supergene examples include the Asbesheuwels Subgroup-hosted ores of the Maremane Dome (Fig. 2) such as Sishen, Khumani, Beeshoek and Welgevonden (the latter also known as Sishen

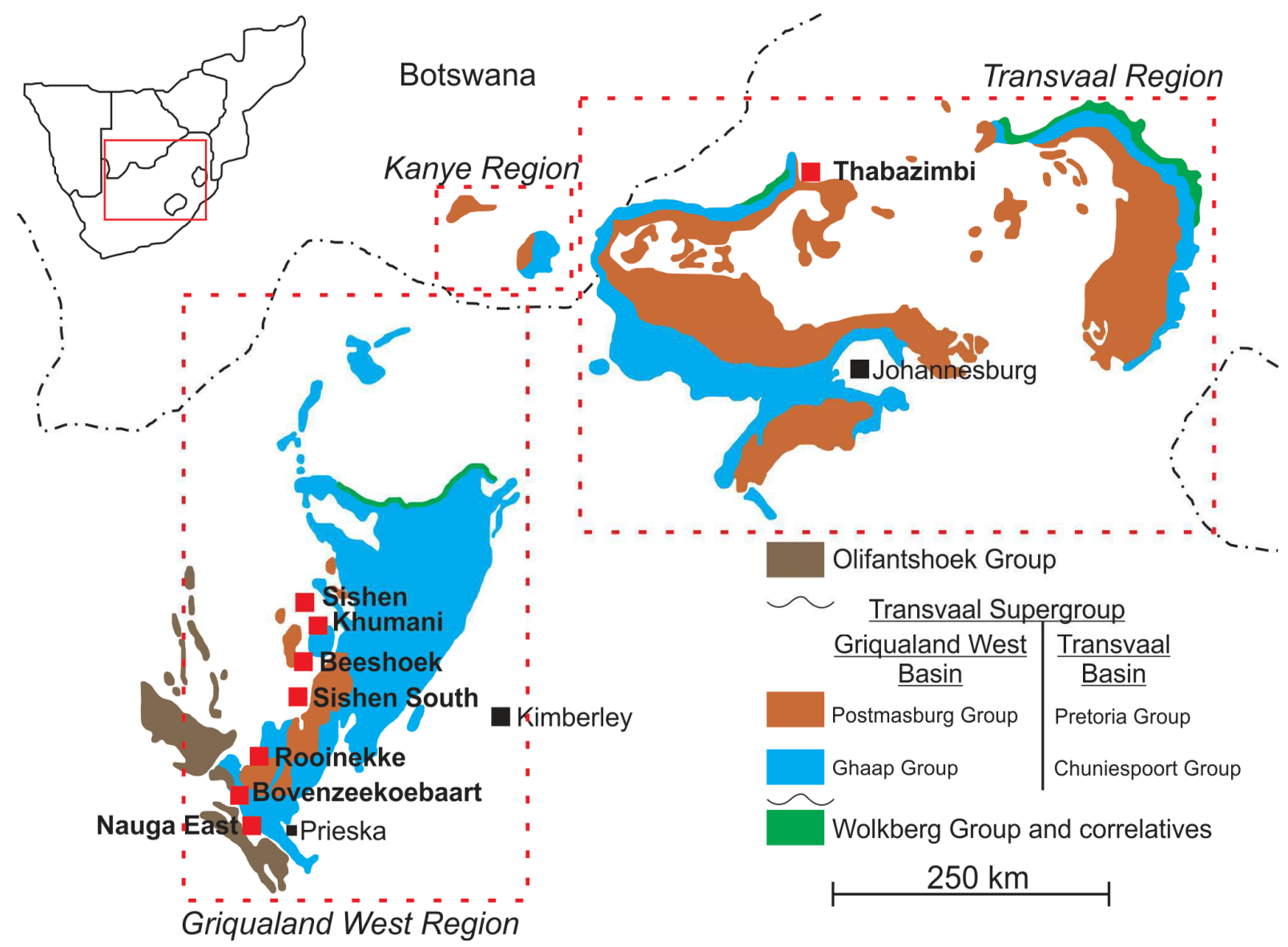

Figure 1: A general locality map indicating the position of the Transvaal and Griqualand West sectors of the Transvaal Supergroup in South Africa. Also illustrated are generalized stratigraphic columns for the Transvaal Supergroup in the Transvaal and Griqualand West areas respectively (Adapted from Eriksson et al., 2006; Van Deventer, 2009). 
South and mined in Kolomela Mine); the Koegas Subgroup-hosted Rooinekke deposit; and the Hotazel Formation-hosted ores in the Kalahari Manganese Field (KMF) (Fig. 1). Hydrothermal deposits include the Penge Iron Formation-hosted deposit at Thabazimbi and the Kuruman Iron Formation-hosted deposits at Bovenzeekoebaart and Nauga East (Fig. 1). The latter deposit is also considered to be a magmatically induced hydrothermal end member deposit (Gutzmer et al., 2008). This contribution aims to summarize and compare the geological setting, petrography, geochemistry and genesis of the BIF-hosted iron ores of the Transvaal Supergroup based upon previously published material as well as recent field work by the authors.

\section{History of BIF-hosted iron ore mining in South Africa}

Currently, the bulk of South Africa's high-grade BIF-hosted iron ore production comes from four mines on the Maremane Dome in Griqualand West, namely the Sishen and Khumani Mines along the northern margin of the dome, and the Beeshoek and Kolomela Mines in the south (Fig. 2). In 2014 these produced 76.9 million tonnes [Mt] of high-grade hematite ore with the remaining $1.1 \mathrm{Mt}$ coming from the Thabazimbi mine (USGS, 2015; Kumba annual results, 2014). The Rooinekke Mine produced small tonnages of manganiferous high-grade hematite for a few decades up to about

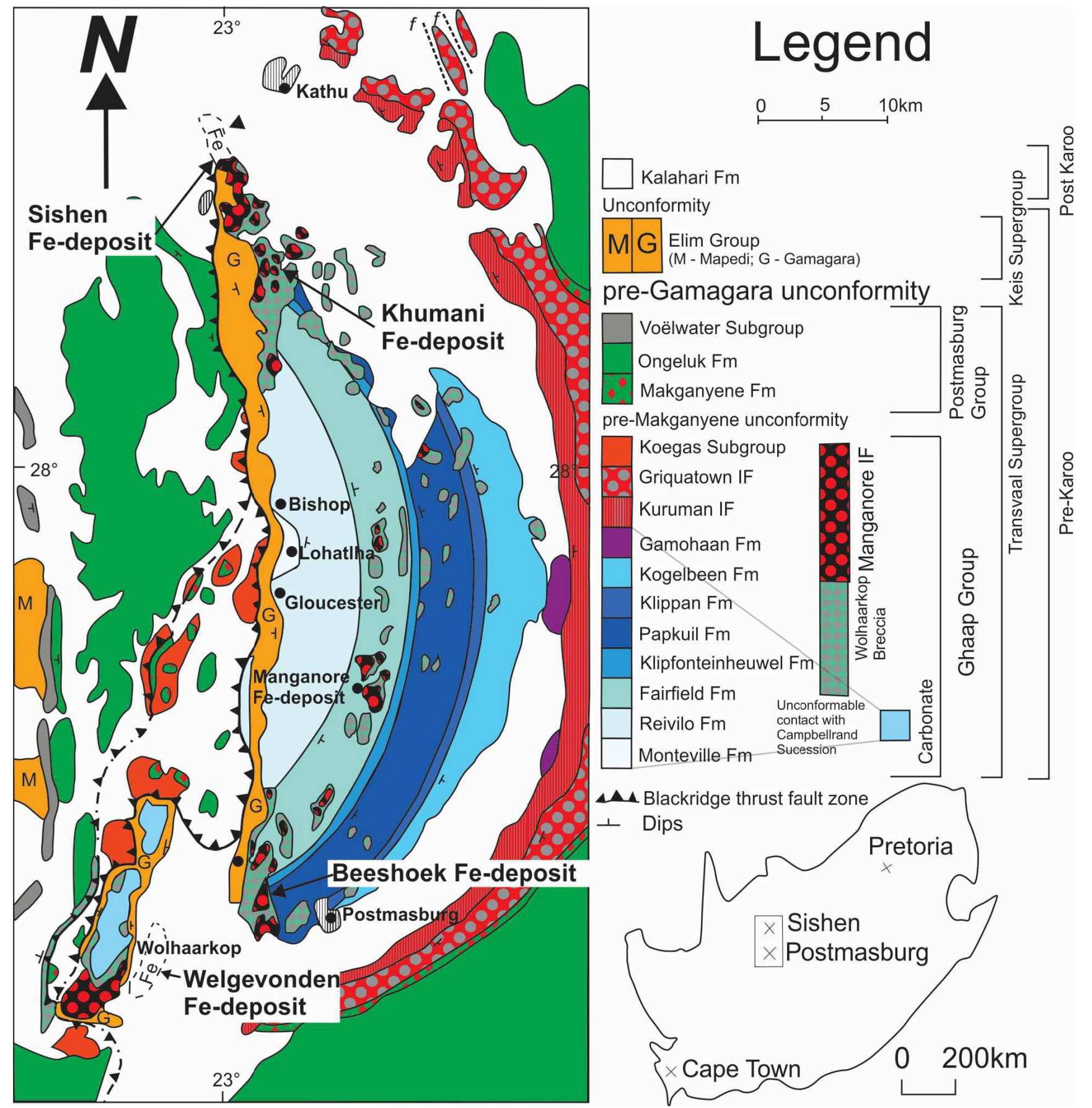

Figure 2: Regional geological map of the Maremane Dome region in the Northern Cape Province indicating the location of the Sishen, Khumani, Beeshoek and Sishen South iron ore deposits (modified after Van Schalkwyk and Beukes, 1986). 
1990 but is currently closed. The Nauga East deposit has been investigated by small scale inclined tunneling, the Bovenzeekoebaart deposit by field mapping and exploration drilling and the ores of the Hotazel iron formation are only known from intersections in exploration drill cores for manganese and a few exposures in mines of the Kalahari Manganese Field (KMF).

The extraction and use of BIF-hosted iron ore in South Africa can be dated back to between 800 and 1200 AD when Khoisan miners extracted specularite from Doornfontein in the Northern Cape Province (Cairncross et al., 1997). Other pre-colonial mining activities include: the extraction of specularite used for cosmetic purposes at Blinkklipkop close to Postmasburg in the Northern Cape Province, by local Tswana inhabitants (Cairncross et al., 1997); and mining shafts and furnaces dating from $1500 \mathrm{AD}$ in the Thabazimbi area (Netshiozwi, 2002). However, industrial production of BIF-hosted iron ore only commenced in 1931 when a company with the name South African Manganese, from which SAMANCOR later developed, supplied 1,400 tonnes of hematite iron ore from the Maremane dome to a blast furnace at Newcastle in KwaZulu-Natal, for the production of pig iron. Prior to that, all production of iron ore for pig iron in South Africa came from oolitic iron ore deposits of the Timeball Hill Formation of the Pretoria Group of the Transvaal Supergroup at Pretoria (Cairncross et al., 1997). This operation was initiated by an engineer named Cornelius Delfos in 1916. It was also from these oolitic iron ores that the first steel was produced in South Africa by the Steel Corporation of South Africa (ISCOR) in the early 1930s. However, very soon these deposits could not keep up with demand for ore from the Steel Works and in 1931 the Thabazimbi Iron Ore Mine was opened (Netshiozwi, 2002), to supply high-grade BIF-hosted hematite ore to the steel works, a function it still performs after eight decades, though now on a small scale.

Large scale production of high-grade BIF-hosted hematite ore from the Maremane Dome in Griqualand West commenced in 1953 with the opening of the Sishen Iron Ore Mine by ISCOR, mainly to fulfill demand for high-grade iron ore from their new steelworks at Vanderbijlpark. Export of the high-grade hematite ores from the Maremane dome first took place in 1964 via Port Elizabeth harbour (1,106 km distance) from ASSMANG's newly opened Beeshoek Mine near Postmasburg. Export of the ores in amounts of several tens of millions of tonnes per annum from the area, however, only started in 1976 from Sishen Mine after completion of the Sishen-Saldanha railway line over a distance of $851 \mathrm{~km}$ (Cairncross et al., 1997). In recent years two major new mines have come into production on the Maremane Dome: Khumani, owned by ASSMANG, immediately south of Sishen, in 2008; and Kolomela, owned by Kumba, south of Beeshoek, in 2011 (Fig. 2).

\section{Geological setting}

\section{Supergene ores}

The most well-known supergene iron ores of the Transvaal Supergroup occur in the Northern Cape Province within the Maremane Dome, along an approximately $90 \mathrm{~km}$ long north-south trending line perpendicular to the fold axis of a double plunging anticline, between the towns of Sishen in the north and Postmasburg in the south (Fig. 2). The Maremane Dome dips gently to the east and is mostly composed of the dolostones of the Campbellrand Subgroup and iron formations of the Asbesheuwels Subgroup. An erosional unconformity, called the pre-Gamagara unconformity (also known as the Mapedi unconformity), cuts through this anticline and is succeeded by the Gamagara/Mapedi red bed succession (Fig. 3B). The unconformity, which is regionally developed over the entire Griqualand West area, is consistently marked by the presence of a ferruginous lateritic weathering profile in the rocks immediately below (Fig. 3A). Formation of the unconformity and weathering took place around 2.2 to $2.0 \mathrm{Ga}$, at the time of lower Elim Group deposition (Dalstra and Rosière, 2008), following a period of folding and uplift of Transvaal Supergroup strata. Because of the folded nature of the strata below, the unconformity transects a wide variety of rocks, the compositions of which determine lateral variations along the lateritised surface (Fig. 3A and B). Towards the west of the Maremane Dome, older rocks of the Transvaal Supergroup, including the Koegas Subgroup, Makganyene diamictite and Ongeluk lava, have been thrust over the post-Mapedi/Gamagara units along the Black Ridge thrust (Fig. 2) (Beukes and Smit, 1987).

High-grade hematite iron ores are only developed in areas where the unconformity transects BIF. Well-known high grade iron ore deposits developed below the pre-Gamagara/Mapedi unconformity include the Sishen, Khumani, Beeshoek, Welgevonden (Sishen South) and Rooinekke deposits (Fig. 3A and B). The ores are apparently derived from the leaching of chert from the BIF during supergene alteration. Three iron formation successions are involved, namely: (i) the Asbesheuwels Subgroup, comprising the Kuruman and Griquatown Iron Formations overlying Campbellrand Subgroup carbonates; (ii) the Rooinekke Iron Formation of the Koegas Subgroup; and (iii) the Hotazel Iron Formation overlying basaltic andesites of the Voëlwater Subgroup (Fig. 3A).

However, large to superlarge deposits of high-grade iron ore are only developed in karstic laterite settings, where Asbesheuwels BIF has slumped into carbonates of the underlying Campbellrand Subgroup along the Maremane dome (Fig. 3B). In this region the enriched sections of the Asbesheuwels Subgroup in these karstic slump structures are also known as the Manganore Formation (Beukes, 1978; Van Schalkwyk and Beukes, 1986). The iron ores are typically overlain by reworked conglomeratic iron ores of the Doornfontein Member of the Elim Group, Keis Supergroup, as well as highly aluminous diaspore-rich shales and closely associated pisolitic lateritic palaeosol profiles (Van Schalkwyk and Beukes, 1986; Gutzmer and Beukes, 1998; Gutzmer et al., 2008). From the unconformity contact downwards, the ore grades into oxidized BIF mostly of the Kuruman Iron Formation. Iron ore can also occur below the main ore body within the BIF as ore lenses. Brecciation and associated specularite veinlets are common throughout the ore and BIF. Multiple dolerite sills also intersect the BIFs and ore at various stratigraphic levels. Although these sills are highly ferruginized themselves, there is no clear iron upgrade of the ore or BIF associated with the sills. A siliceous chert breccia, known as the Wolhaarkop breccia, marks the dissolution surface between the dolomite and overlying ore-bearing iron formation (Fig. 3B). In areas outside of karst slump structures only thin (1-2 m thick) high-grade hematite ore beds are locally preserved below the unconformity. This is, for example, the case where the unconformity transects the Hotazel Formation in the KMF (Fig. 3A). However, this upper lateritic iron ore capping has often been removed by erosion prior to deposition of the overlying Gamagara red beds. In such cases, only a thick oxidized palaeoweathering profile, without removal of chert, is preserved in the underlying iron-formation. 


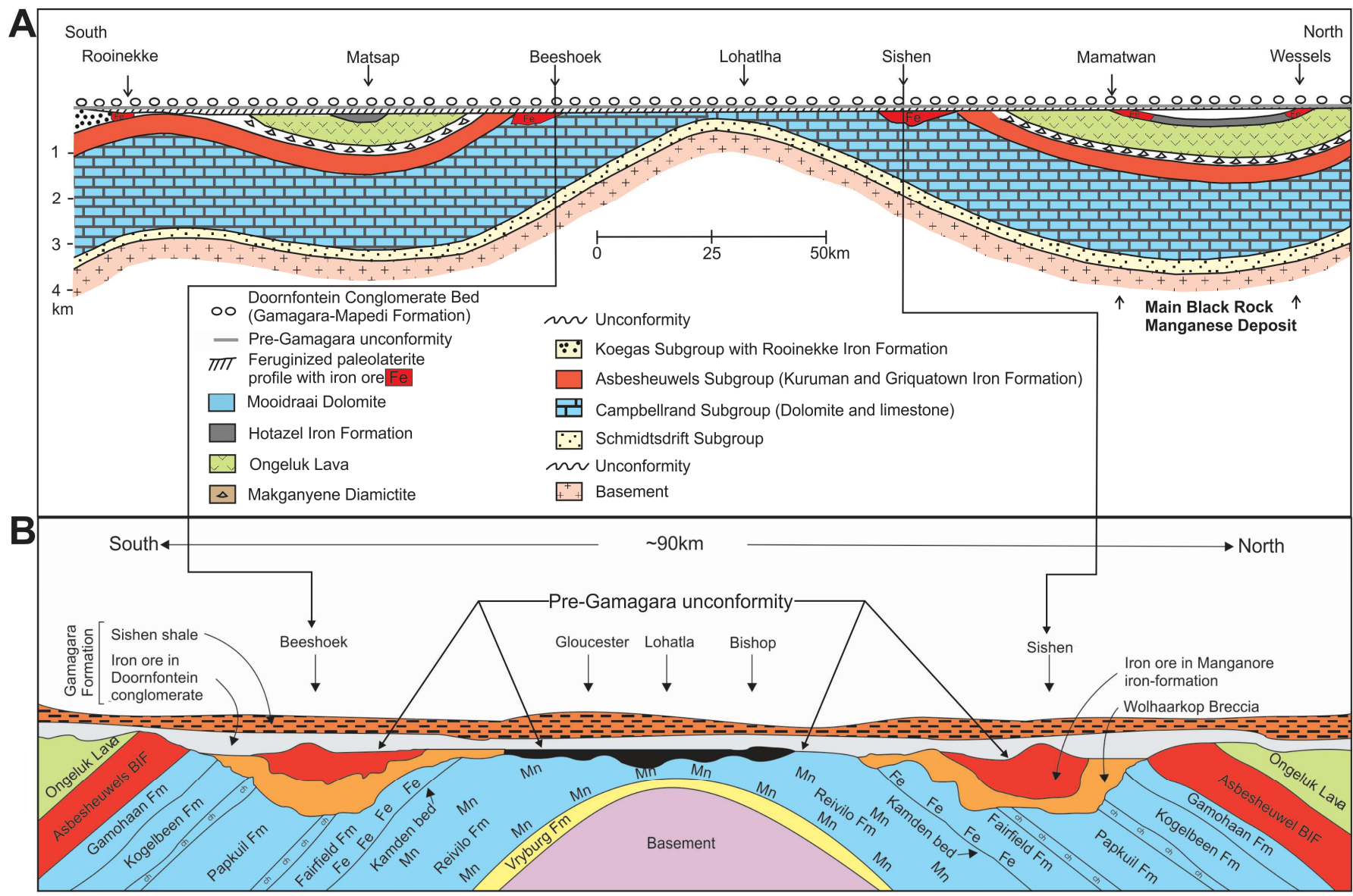

Figure 3. A schematic north-south cross section through (A) the western margin of the Griqualand West area and (B) the Maremane Dome (modified after Cairncross et al., 1997; Van Deventer, 2009). Sub-surface dips of lithologies are exaggerated for illustrative purposes.

The Rooinekke deposit is situated approximately $60 \mathrm{~km}$ west of Griquatown in the Northern Cape Province (Fig. 1) and is hosted in the Rooinekke Iron Formation of the Koegas Subgroup (Fig. 3A). The Koegas Subgroup overlies the Asbesheuwels Subgroup and is composed of mudstone, siltstone, quartzite and iron formations (Grobbelaar et al., 1995; Nel, 2013). Just as with the Maremane Dome, the area around Rooinekke is characterized by deformation in the form of regional open folding. In the Rooinekke deposit area, the top of the Campbellrand, Kuruman and Koegas Subgroups have been thrust onto the Keis Supergroup (Grobbelaar et al., 1995) by the previously mentioned Black Ridge Thrust (Beukes and Smit, 1987). The Rooinekke iron ore is developed at the contact between the Rooinekke Iron Formation and the pre-Gamagara/Mapedi unconformity (Holland and Beukes, 1990) which is, in turn, overlain by the Mapedi Shale of the Keis Supergroup. The base of the Mapedi Shale at Rooinekke is also marked by a basal lag and the overlying conglomerate, which correlates to the Doornfontein Member in the Maremane Dome, contains hematite pebbles (Grobbelaar et al., 1995).

The Hotazel Formation of the Voëlwater Subgroup, which conformably overlies the Ongeluk Lavas towards the top of the Transvaal Supergroup, also contains BIF-hosted iron ores in some areas that occur in close association with the manganese ores of the KMF. These medium to high grade iron ore units are at most a few metres thick and are developed where the pre-Gamagara/Mapedi unconformity intersects the Hotazel Formation within the KMF (Fig. 3A; Gutzmer, 1996; Chisonga, 2012). The BIFs of the Hotazel Formation occur as four units and form part of three broad sedimentary cycles marked by manganese beds at their centres (M1, M2 and M3 manganese beds), grading into hematite lutite and BIF above and below. Depending on the stratigraphic position of the pre-Gamagara unconformity in an area, iron ore can be developed in any of the four BIF units. Ores developed towards the base of the Hotazel Formation are not as thick and laterally continuous as those developed towards the top (Chisonga, 2012).

\section{Hydrothermal ores}

The best known hydrothermal BIF-hosted iron ore deposit in South Africa occurs close to the town of Thabazimbi in Limpopo Province (Fig. 1). It is situated along the east-west trending Mohlapitsi fold belt (Netshiozwi, 2002) and is hosted within the Penge Iron Formation in the Transvaal Basin of the Transvaal Supergroup. Two major east-west striking mountain ranges and one major north-south striking mountain range occur in the area, with major ore occurrences in the east-west striking mountain ranges (Netshiozwi, 2002). The Penge Iron Formation at Thabazimbi is underlain by the Malmani Dolostone and overlain by shales of the Timeball Hill Formation. Due to its location within the Mohlapitsi fold belt as well as the occurrence of two major east-west trending thrust fault systems, the Penge Iron Formation in the region is intensely folded and faulted (Du Plessis, 1990; Netshiozwi, 2002). The ore occurs as strata-bound lenses near the base of the deformed BIF in contact with underlying black shale (Beukes et al., 2003; Gutzmer et al., 2008). Dolerite sills and dykes also intrude and crosscut the BIF. Just as observed with 
the ores of the Maremane Dome (previous section), the associated BIF at Thabazimbi has been oxidized (i.e. hematitized; Netshiozwi, 2002).

Less well-known hydrothermal BIF-hosted iron ore deposits in South Africa include the Kuruman Iron Formation-hosted Bovenzeekoebaart and Nauga East Deposits in the Northern Cape Province of South Africa. The Bovenzeekoebaart deposit is situated approximately $65 \mathrm{~km}$ northwest of the town of Prieska. It consists of two major strata-bound lenses of steeply dipping and overturned iron ore at the base of the Kuruman Iron Formation and has a conformable contact with the underlying Klein Naute shale and dolostones of the Nauga Formation of the Campbellrand Subgroup. The associated BIF is hematitized and intensely deformed and folded. The southwest to northeast trending Doringberg fault system cuts the Kuruman Iron Formation in this area and is associated with major vertical displacements (Harding, 2004). The Kuruman Iron Formation east of the deposit is intruded by the Leelykstraat diabase sill that predates deformation, and all mineralisation is concentrated between the sill and the Klein Naute shale (Harding, 2004). Complex boxworks of deformed quartz veins transect the Kuruman Iron Formation above and the Klein Naute shale below the ore lenses. The shale and BIF within which the quartz veins occur, are highly ferruginized and magnetic. The contacts between ore lenses and the surrounding strata are difficult to delineate in the field and appear to be gradual.

\section{Magmatically induced hydrothermal ores}

The Nauga East BIF-hosted iron ore deposit is situated $15 \mathrm{~km}$ from the town of Koegas in the Northern Cape Province. The deposit is marked by up to $40 \mathrm{~m}$ thick tabular high grade ore bodies (two major and one minor), developed where a steeply dipping zoned syenite-carbonatite dyke crosscuts the Kuruman Iron Formation (Harding, 2004; Gutzmer et al., 2008). Just as at Bovenzeekoebaart, highly oxidized Kuruman BIF overlies the Klein Naute shale and dolostones of the Nauga Formation of the Campbellrand Subgroup. The zoned syenite-carbonatite dyke appears to have intruded along a set of north-south trending joints. The dyke follows the contact between the Kuruman BIF and Klein Naute shale in the south, but towards the north it crosscuts the BIF (Harding, 2004). The dyke is generally considered to be the footwall to the ore, and the ore grades upwards into oxidized BIF (Harding, 2004).

\section{Description of currently mined deposits}

Supergene high grade BIF-hosted iron ore deposits from which significant quantities of iron ore are currently produced include, from north to south, the Sishen, Khumani, Beeshoek and Kolomela deposits (Fig. 1), which are all situated in the Maremane Dome (Figs. 2 and 3B). The only BIF-hosted hydrothermal high grade iron ore deposit of the Transvaal Supergroup from which significant iron ore production occurs is the Thabazimbi deposit in the Transvaal Basin (Fig. 1). The Rooinekke, Hotazel, Bovenzeekoebaart and Nauga East deposits are not discussed in this section as they are either not currently producing high grade iron ore, or have not been developed for mining.

\section{Sishen deposit}

Sishen Mine is one of the world's major, high-grade, lump ore producers and is owned by Kumba Iron Ore. From December 2013 to December 2014 the mine produced 35.5 Mt of ore (Kumba annual results, 2014) from one continuous pit (Carney and Mienie, 2003). At the end of 2014, Sishen's life of mine was estimated at 16 years (Kumba annual results, 2014). The mine is situated at the northern extremity of the Maremane Dome directly to the west of the town of Kathu (Fig. 2). Four ore types occur, namely: laminated; massive; brecciated and conglomeratic ore (Van Schalkwyk and Beukes, 1986; Carney and Mienie, 2003). The laminated and massive ores form part of what were originally the Kuruman and Griquatown Iron Formations of the Asbesheuwels Subgroup. Brecciated ore also occurs within the latter stratigraphy, but is better developed within deep palaeosinkholes on the southern portion of the deposit (Beukes and Gutzmer, 2008a). A sill is commonly found between the ore and the underlying BIF and is generally less than $2 \mathrm{~m}$ in thickness (Carney and Mienie, 2003). The conglomeratic ore occurs above the preGamagara/Mapedi unconformity within the Doornfontein Member conglomerate of the Gamagara Formation and comprises detritally reworked laminated and massive ore. The previously mentioned Black Ridge thrust has emplaced the Makganyene diamictite and Ongeluk lavas of the Transvaal Supergroup on top of the Gamagara Formation lithologies towards the west of the deposit (Beukes and Gutzmer, 2008a).

Although the Sishen ore deposit is fairly continuous when compared to other deposits in the region, different ore bodies are recognized, namely the North, Middle, and South Mines (Beukes and Gutzmer, 2008a). Interference folds, leading to basin and dome structures throughout Sishen (Fig. 4 A), have been modified by normal faulting and low angle thrusts (Carney and Mienie, 2003). The ore is best preserved within the basin structures with only barren footwall occurring in the domal structures (Fig. 4 A) (Carney and Mienie, 2003). The floor and thickness of the ore bodies are irregular due to their karstic setting. Early joint systems in the underlying dolostones are believed to have had a strong influence on the development of early karst structures and therefore the structure of the ore deposit (Van Schalkwyk and Beukes, 1986; Beukes and Gutzmer, 2008a).

\section{Khumani deposit}

The Khumani deposit is mined from the Khumani Iron Ore Mine and is owned by Assmang. The mine produces approximately $10 \mathrm{Mt}$ of high grade iron ore per annum, with recent expansion projects increasing annual production to approximately $14 \mathrm{Mt}$ (www. assmang.co.za). At the end of 2014 Khumani was estimated to have a remaining mineable reserve of $550 \mathrm{Mt}$ (Assmang integrated annual report, 2014), translating to an approximate life of mine of 39 years under current annual production and iron ore prices. The deposit is situated north of the fold axis of the Maremane Dome, approximately $30 \mathrm{~km}$ south of the town of Kathu (Fig. 2) on the farm Bruce, and represents a southern extension of the Sishen deposit, as well as on the farms King and Mokaneng to the south (Beukes and Gutzmer, 2008a). The general stratigraphy and ore types in the northern parts of Khumani are therefore very similar to those encountered at Sishen, which include Transvaal Supergroup lithologies thrust over the Gamagara Formation to the west. However, the ores at Khumani occurred in outcrop and suboutcrop before mining production began, whereas those at Sishen originally dipped below the Gamagara and Kalahari lithologies (Beukes and Gutzmer, 2008a). Whereas in the north of the deposit (Bruce farm) Asbesheuwel Subgroup-hosted laminated, massive and brecciated ore makes up $80 \%$ of the mineable 


\section{A}

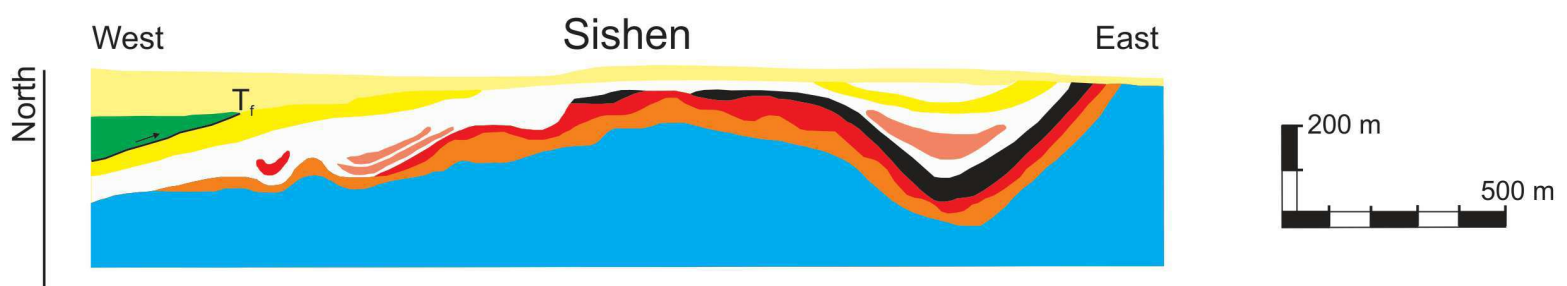

B

West Beeshoek

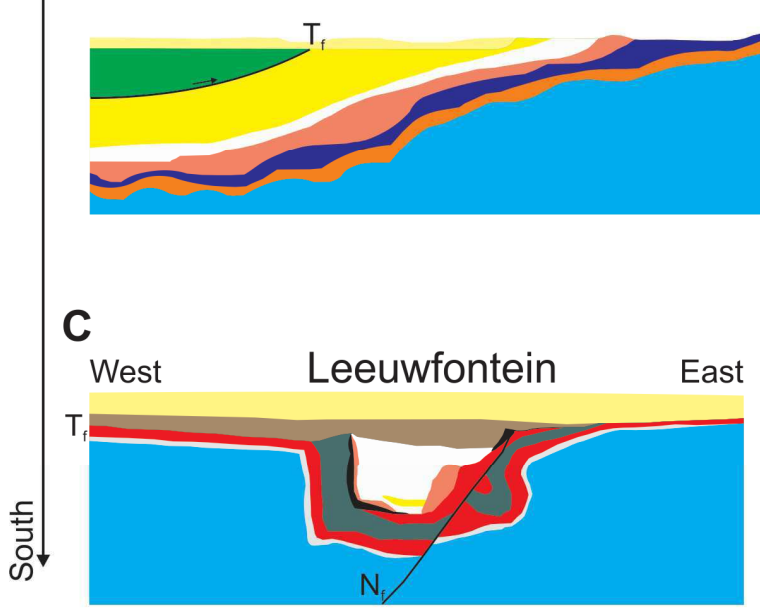

\section{Main stratigraphy}

Kalahari sediment cover

Dwyka diamictite

Ongeluk Lava

$\rightarrow \mathrm{T}_{\mathrm{f}}$ Blackridge thrust

Marthaspoort quartzite

$\square$ Sishen shale

Ore pebbles (conglomeratic ore)

BIF pebbles

$\sim$ Unconformity

$\square$ Oxic

Laminated/massive ore

Oxidized Kuruman BIF

Wolhaarkop breccia

$\sim$ Solution collapse discontinuity

Campbellrand dolostone

Figure 4: East-west cross sections illustrating the (A) Sishen iron ore deposit (adapted from Carney and Mienie, 2003; Van Deventer, 2009); (B) Beeshoek iron ore deposit (adapted from Van Deventer, 2009); and (C) Leeuwfontein ore body of the Welgevonden iron ore deposit (adapted from Alchin and Botha, 2006).

reserve and Doornfontein Member-hosted conglomeratic ore only $20 \%$ (similar to Sishen), this trend is reversed towards the south of the deposit on the King and Mokaneng farms, with conglomeratic ore making up $80 \%$ of the mineable reserve (Beukes and Gutzmer, 2008a). In addition, hematitized BIF and laminated hematite ore are absent in the south of the deposit, although brecciated Asbesheuwels Subgroup-hosted ore is still present (Van Deventer, 2009).

At the Khumani mine the ore is situated in karstic depressions as illustrated by the irregular floor and thickness of the ore bodies. Two main groupings of ore bodies occur on the farms of Bruce in the north and King in the south respectively (Beukes and Gutzmer, 2008a). When compared to the Beeshoek deposit further to the south, Khumani is characterized by larger stratiform ore bodies (Van Deventer, 2009) and more prominent hanging wall outcrops, due to less erosion having taken place at Khumani.

\section{Beeshoek deposit}

The Beeshoek deposit, also known as the Beeshoek-Olynfontein deposit (Van Deventer, 2009), is mined from the Beeshoek Iron Ore Mine and is owned by Assmang. Between 1994 and 2006 an average of 4.6 Mt of ore produced from the mine was sold annually. At the end of 2014, Beeshoek had a remaining mineable reserve of approximately $46 \mathrm{Mt}$ (Assore integrated annual report, 2014). The deposit is situated south of the fold axis of the Maremane Dome, approximately $7 \mathrm{~km}$ west of the town of Postmasburg (Fig. 2). The general stratigraphy and ore types are similar to those encountered at Sishen and Khumani, which includes Transvaal Supergroup lithologies thrust over rocks of the Gamagara Formation to the west (Grobbelaar et al., 1995). Conglomeratic ore is generally more common at Beeshoek (Fig. 4B), especially towards the north of the deposit, than at the Sishen and Welgevonden deposits.

The Beeshoek ore bodies are preserved in localized, smaller depressions in the form of sinkholes (Fig. 4B) (Grobbelaar et al., 1995). A very prominent structural feature at the Beeshoek deposit is pre-Kalahari to present day erosional karstic slumping.

\section{Welgevonden (Sishen South) deposit}

The Welgevonden deposit, also known as the Sishen South deposit, is located on the southern extremity of the Maremane Dome, $9 \mathrm{~km}$ southwest of the town of Postmasburg and $65 \mathrm{~km}$ south of 
Sishen Mine (Fig. 2) (Carney and Mienie, 2003). The deposit is made up of several smaller ore bodies and is currently mined at Kolomela Mine under the ownership of Kumba Iron Ore. From December 2013 to December 2014 the mine produced 11.6 Mt of ore from three pits and Kolomela's life of mine was estimated at 21 years (Kumba annual results, 2014). The general stratigraphy of the Asbesheuwels Subgroup and the overlying Gamagara Formation and the ore types at Welgevonden (Alchin et al., 2008), are similar to those encountered at the Sishen deposit. The only BIF present at Welgevonden appears to be that of the Kuruman Iron Formation, with the Griquatown Iron Formation having been removed by erosion (Alchin et al., 2008). The Gamagara Formation lithologies are truncated by the Dwyka diamictite (Carney and Mienie, 2003; Alchin et al., 2008), and have not had the Transvaal Supergroup lithologies thrust over them as occurs in other parts of the Maremane Dome (Fig. 4C). A gabbroic sill that attains a thickness of up to $30 \mathrm{~m}$ occurs between the ore and the underlying BIF (Carney and Mienie, 2003) (Fig. 4C).

The main structural characteristic in the west of the Welgevonden area is the Wolhaarkop Dome, an overturned anticline replicating the larger Maremane Dome, which occurs in the east of the deposit (Alchin et al., 2008). The Campbellrand Subgroup dolostones, which form the basement of the ore bodies, are exposed at surface in the Wolhaarkop Dome, with ore bodies occurring along the flanks of the dome (Alchin and Botha, 2006). The Welgevonden ore bodies are subdivided into five groups: the Welgevonden, Kapstevel, Klipbankfontein, Ploegfontein and the Leeuwfontein ore bodies (Fig. 4C) (Alchin and Botha, 2006). The ore bodies are intensely folded and faulted, and are preserved within erosional remnants that are not as continuous, but are of similar structural types to those encountered at Sishen (Fig. 4A) (Carney and Mienie, 2003). Two tectono-stratigraphic settings for the ore bodies have been defined by Alchin and Botha (2006): a palaeosinkhole-hosted setting applicable to the Ploegfontein, Leeuwfontein (Fig. 4C) and Klipbankfontein ore bodies; and a synclinal basin setting applicable to the Welgevonden and Kapstevel ore bodies. Marginal deformational effects, thought to be related to the $\sim 2.2 \mathrm{Ga}$ Kheis event, occur towards the west of the deposit and decrease rapidly to the east (Alchin and Botha, 2006). The scattered nature of the ore bodies at Welgevonden could be due to the removal of upper lithologies by erosion (Carney and Mienie, 2003) and/or due to smaller, less connected underlying palaeosinkhole, pseudo-graben and synclinal structures. The Sishen South deposit is also much smaller than the main ore body at Sishen and early exploration estimates put its mineable ore reserves at approximately $25 \%$ of those at Sishen (Carney and Mienie, 2003).

\section{Thabazimbi}

The Thabazimbi deposit occurs next to the town of Thabazimbi which is located approximately $200 \mathrm{~km}$ northwest of Pretoria. The deposit is currently mined at Thabazimbi Mine under the ownership of Kumba Iron Ore and from December 2013 to December 2014 the mine produced 1.1 Mt of ore (Kumba annual results, 2014). Due to the low iron ore price at the end of 2014, the future of the mine was under review, with closure procedures started in mid-2015. At peak production, mining took place within two major east-west striking mountain ranges called the Northern and Southern ranges. Five ore bodies are located within the Northern range, two in the Southern Range with another minor ore body occurring in a smaller east-west striking mountain range called the Middle range (Netshiozwi, 2002).
Due to normal low-angle lystric faults in the area of the deposit, strata of the Malmani Dolostone and Penge Iron Formation are absent. Mineralisation occurs along these normal low-angle lystric faults (Fig. 5A and B) (Beukes et al., 2003; Gutzmer et al., 2008).

The hematite ore occurs in large tabular, stratabound ore bodies in the basal and lower parts of the Penge Iron Formation (Fig. 5A), with some duplication of the ore bodies having been caused by eastwest trending thrust faults. Three stratigraphic types of ore bodies, namely the basal, upper and lenticular types are distinguished, of which the basal type is the most common (Netshiozwi, 2002). The basal type ores occur as tabular ore bodies developed along the BIF and shale contact and pinch out laterally (Fig. 5A). The upper type ores only occur above a diabase sill that cuts the succession (Fig. 5B) and are tabular and stratabound. The lenticular type ores occur as small irregular lenses at different stratigraphic levels in the middle to lower parts of the BIF (Netshiozwi, 2002). Although there are some differences between the ore bodies of the Thabazimbi deposit, numerous commonalities occur. The basal, tabular ore type is most common throughout and generally dips steeply $\left(\sim 35-55^{\circ}\right)$ along the basal BIF-shale contact. In numerous cases hematite ore grades into carbonate ore at depth (Fig. 5A). As previously mentioned, a diabase sill occurs within the Penge Iron Formation at different stratigraphic levels above the basal ore bodies. The entire stratigraphy of some of the ore bodies is cut by northwest to southeast trending diabase dykes (Fig. 5A) (Netshiozwi, 2002). Some of the deposits show slumping into karstic structures up dip at shallower depths, with some friable

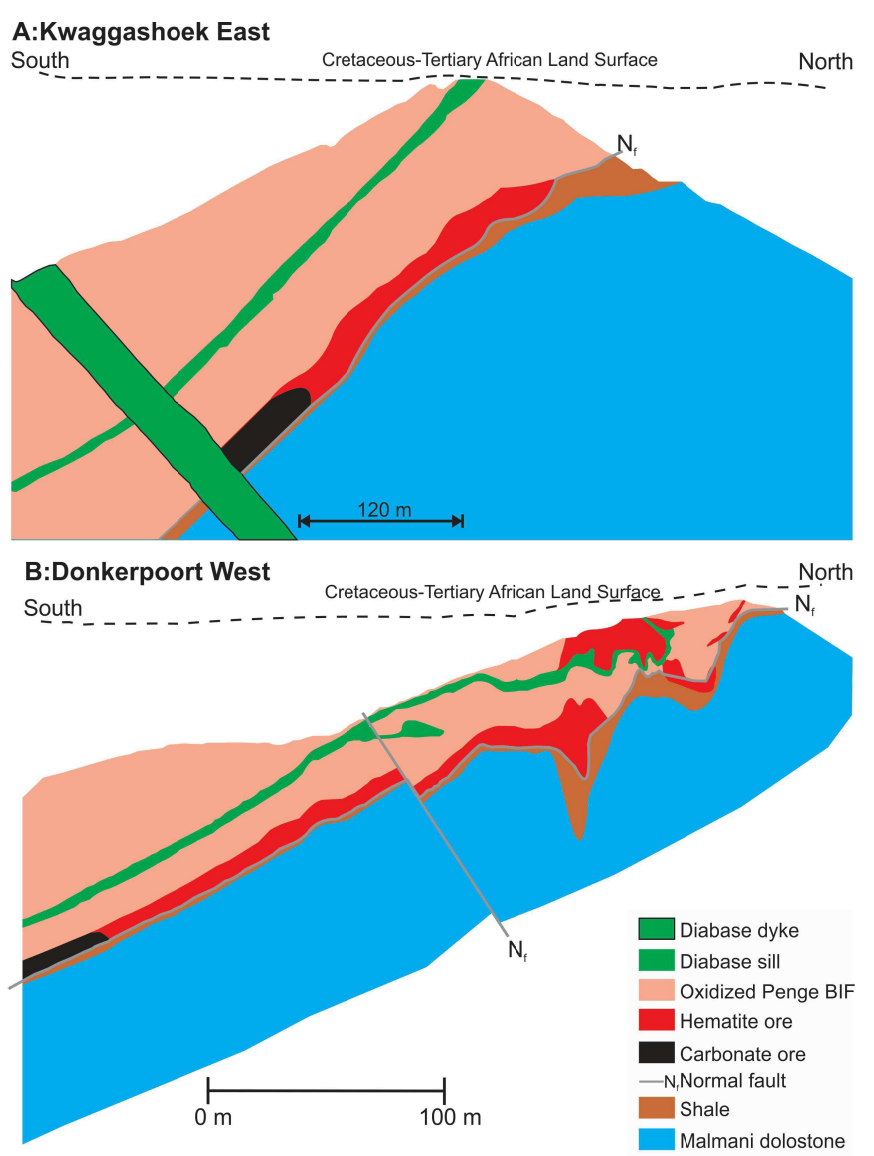

Figure 5. North-south cross section through the (A) Kwaggashoek East and (B) Donkerpoort West ore bodies that occur within the Northern range of the Thabazimbi iron ore deposit (adapted from Netshiozwi, 2002). 
supergene ore developed on outcrops (Fig. 5B). The karstification and supergene enrichment is likely related to the weathering of the Cretaceous-Tertiary African land surface to form post-African land surfaces (Partridge et al., 2006).

\section{Petrography of iron ores}

The following is a short summary of the main textural types of ore and hematite encountered within the Transvaal Supergroup-hosted iron ores of South Africa. More detailed petrographic characteristics and mineralogy can be found in Van Schalkwyk and Beukes (1986), Netshiozwi (2002), Carney and Mienie (2003) and Harding (2004).

Four ore types are present in the major supergene BIF-hosted iron ore occurrences within the Griqualand West area, namely: laminated (Fig. 6a); massive (Fig. 6b); brecciated (Fig. 6c); and conglomeratic ore (Fig. 6d) (e.g. Van Schalkwyk and Beukes, 1986; Carney and Mienie, 2003; Alchin et al., 2008). The exception is in the Hotazel Formation-hosted ores, where brecciated and conglomeratic ores are generally less abundant or absent (Chisonga, 2012). Laminated, massive and brecciated ores occur within the BIF sequences, whereas conglomeratic ore occurs above the pre-Gamagara unconformity in the Doornfontein Member conglomerate.

Hydrothermal ores are all BIF-hosted and show the same three main textural types as the supergene ores, namely laminated, massive (Harding, 2004) and brecciated ore (Netshiozwi, 2002). In addition to the main three ore types, carbonate-hematite brecciated ores as well as supergene modified ores, are also encountered at Thabazimbi (Netshiozwi, 2002). The carbonate-hematite brecciated ores contain more than ten volume percent secondary sparitic carbonates, whereas the supergene modified ores have been modified in modern times and can be friable, porous or goethite-rich. The magmatically induced hydrothermal ores at the Nauga East deposit, mostly show a massive texture (Harding, 2004).

In both the supergene and hydrothermal ores, the laminated ores appear to have been derived from enrichment of microbanded BIF (termed ferhythmite) (Fig. 6e), whereas massive ores appear to represent enriched clastic-textured muddy BIF (termed lutite) (Fig. 6f) (see Beukes and Gutzmer, 2008b, for BIF classification) respectively. The ores are mostly composed of fine-grained compact hematite aggregates in three main textural occurrences: microplaty (lathlike and tabular) hematite, patchy hematite (Fig. $6 \mathrm{~g}$ ) and hematite pseudomorphs of magnetite (also termed martite) (Fig. 6i) and iron-rich carbonates. Massive ores are mostly composed of one or the other textural hematite type, whereas the bedding observed in laminated ores is due to alternating bands of microplaty hematite and martite. Bands with abundant microplaty hematite are also sometimes marked by voids. The hematite plates can be bedding parallel but are mostly randomly orientated. Other minerals present include

$\mathrm{H}$

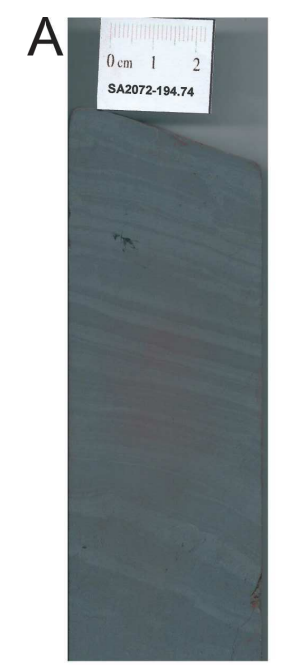

minor quartz and trace amounts of micas, clays and apatite. Brecciated ore is composed of angular blocks of laminated and massive ore in a fine grained hematite and quartz matrix. Conglomeratic ore is composed of subrounded to angular clasts of laminated and massive ore in a muddy, hematite-rich matrix.

Specularite veinlets crosscut underlying oxidized BIF as well as the ore and are especially abundant in brecciated ore (Fig. 6h). They are composed of coarser grained microplaty hematite (i.e. specularite) in random orientations, along with major quartz and in some cases can contain calcite.
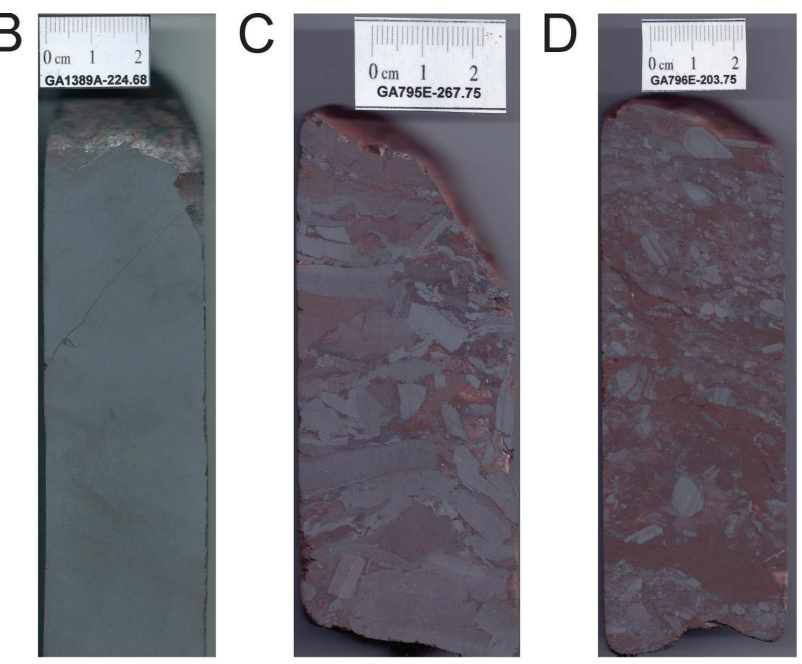
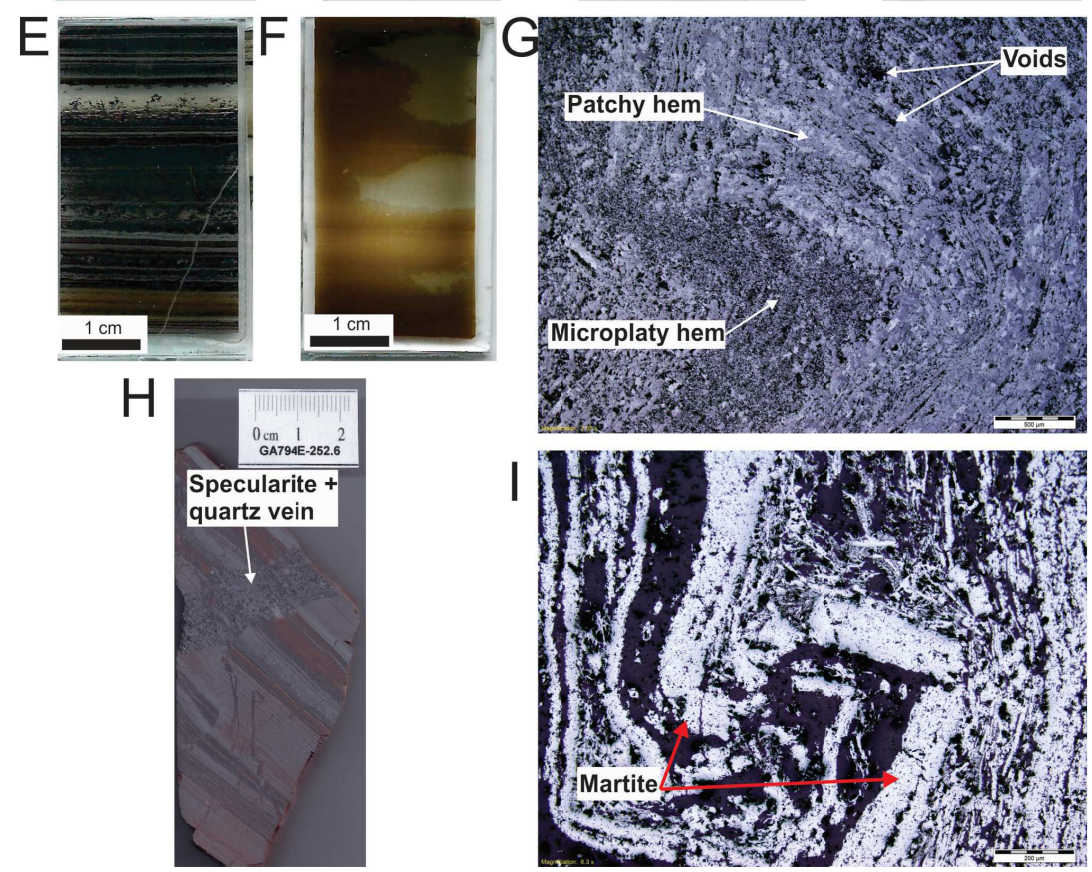

Figure 6: Core scans $(A-D$ and $H)$, thin section scans $(E$ and $F)$ and reflected light photomicrographs ( $G$ and $I)$ of the main ore types encountered in the Transvaal Supergroup-hosted high grade iron ores of South Africa. The main ore types are: A) laminated; B) massive; C) brecciated; and D) conglomeratic ore. Thin section scans illustrate the likely protoliths of laminated and massive ore, namely Kuruman Iron Formation-hosted $E$ ) ferhythmite and $F$ ) stilpnomelane lutite respectively. The photomicrographs illustrate the main textural types of hematite present: $G$ ) microplaty; patchy; and I) martite hematite. A specularite vein with associated quartz that occurs commonly throughout the ore and its surrounding stratigraphy is illustrated in $\mathrm{H}$. All samples are from exploration drill core from Sishen mine except for $E$ and $F$, which are from deep level drill core that intersected unaltered Kuruman Iron Formation. 


\section{Geochemistry}

A compilation has been made from published and unpublished literature of the average major element (Fig. 7) and rare earth yttrium (REY) geochemistries (Fig. 8) of the different Transvaal Supergrouphosted iron ore occurrences in South Africa as well as their host, unaltered BIF. In addition, literature values for hematite stable oxygen isotope $\left(\delta^{18} \mathrm{O} \%\right.$ o $)$ normalized to Standard Mean Ocean Water (SMOW) from the ore occurrences, are also presented (Fig. 9) and discussed.

\section{Major element geochemistry}

Average major element geochemistries of supergene, hydrothermal and magmatic hydrothermal BIF-hosted iron ores of the Transvaal Supergroup, when compared to their unaltered precursor BIFs, illustrate that a strong upgrade in $\mathrm{Fe}_{2} \mathrm{O}_{3}$ contents has taken place (from $\sim 33-46 \mathrm{wt} \%$ to $\sim 73-98 \mathrm{wt} \%$ ) (Fig. 7A). All the ores are high grade ores ( $\sim 60-69 \mathrm{wt} \% \mathrm{Fe})$, with the exception of the Rooinekke ore ( $\sim 50 \mathrm{wt} \% \mathrm{Fe}) . \mathrm{SiO}_{2}$ contents have decreased drastically from the unaltered BIF to the ore (from $~ 46-52 \mathrm{wt} \%$ to less than $4 \mathrm{wt} \%$, with the exception of Rooinekke ore) (Fig. 7B), illustrating highly effective leaching of silica by both supergene and hydrothermal fluids during ore formation processes.

$\mathrm{MnO}$ contents in the Kuruman-Penge BIFs and ores are generally low (less than $0.3 \mathrm{wt} \%$ ) (Fig. 7C), with a decrease observed from $\mathrm{BIF}$ to ore, suggesting manganese mobilization and removal by ore forming processes. However, the manganese-oxide [MnO] contents in the Rooinekke BIFs and iron ores are drastically higher, with a significant upgrade from the BIF $(\sim 2.9 \mathrm{wt} \%)$ to the ore $(\sim 10.1 \mathrm{wt} \%)$. This suggests that at Rooinekke, manganese was immobile and enriched in a similar way to iron during the supergene ore forming event (Gutzmer and Beukes, 2002). The MnO contents in the Hotazel BIFs and iron ores are also significantly higher ( 2.1-2.4 wt \%), as expected due to its close stratigraphic relationship to the KMF manganese ores. For the Maremane and Hotazel BIF and ores, $\mathrm{Al}_{2} \mathrm{O}_{3}$ contents show a prominent upgrade in concentration from the unaltered BIF ( 0.1-0.3 wt $\%)$, to the supergene ores ( 1.2-1.5 wt $\%$ ) (Fig. 7D). The large upgrade in average aluminium-oxide $\left[\mathrm{Al}_{2} \mathrm{O}_{3}\right]$ content in the ore relative to the BIF, can be partially explained by the immobility of aluminium during supergene weathering, leading to a residual upgrade. Likely adding to the upgrade is that aluminiumrich ore that formed from an upgrade of aluminium-rich precursors was more representatively sampled than aluminium-rich units are sampled in the BIF. In the hydrothermal ores the $\mathrm{Al}_{2} \mathrm{O}_{3}$ upgrade is less prominent ( $\sim 0.3-0.5 \mathrm{wt} \%)$, and could be accounted for by all the aluminium remaining behind after silica leaching. The Rooinekke ores show a decrease in $\mathrm{Al}_{2} \mathrm{O}_{3}$ contents from the $\mathrm{BIF}$ to the ore.

Phosphorous is a highly detrimental element to iron ore, with elevated concentration leading to brittle characteristics in the iron and steel produced from such ores. The phosphorous-pentoxide $\left[\mathrm{P}_{2} \mathrm{O}_{5}\right]$ contents for the unaltered BIF as well as the ores, are generally below approximately $0.15 \mathrm{wt} \%$ (Fig. 7E). It appears that the $\mathrm{P}_{2} \mathrm{O}_{5}$ is upgraded from the $\mathrm{BIF}$ to the ore, which could be accounted for by the relative immobility of phosphorous during ore forming events. However, the Bovenzeekoebaart ores (more than $0.25 \mathrm{wt} \%$ ) and to a lesser extent the Hotazel ores $(\sim 0.18 \mathrm{wt} \%)$, show higher $\mathrm{P}_{2} \mathrm{O}_{5}$ contents that are suggestive of the ore forming fluids introducing additional phosphorous to these ores.

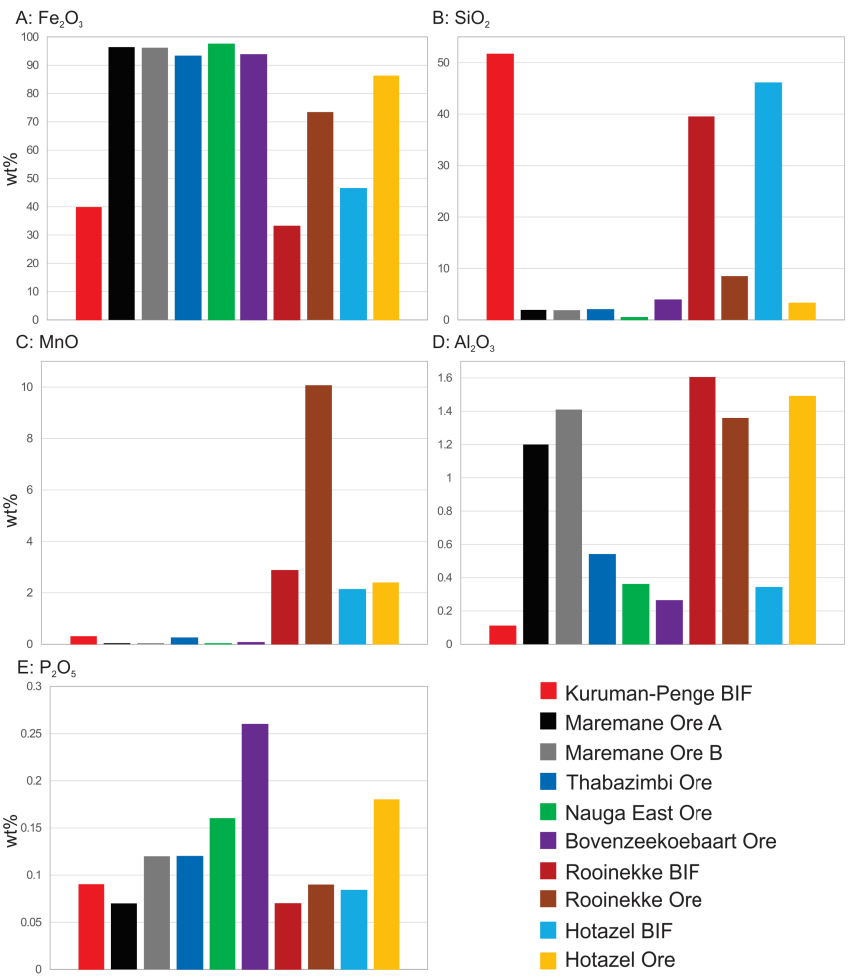

Figure 7: Selected average major element bar graphs from iron ores and their unaltered host BIFs from the Transvaal Supergroup. Data for the Kuruman-Penge BIF ( $n=25)$, Maremane Dome ores ( $n=11$ and $n=16$ for ores $A$ and $B$ respectively), Thabazimbi ores $(n=3)$ and Nauga East ores ( $n=3)$ taken from Gutzmer et al. (2008). Data for the Bovenzeekoebaart ores $(n=3)$ taken from Harding (2004). Data for Rooinekke ore $(n=5)$ and BIF $(n=14)$ taken from Gutzmer and Beukes (2002) and Nel (2013) respectively. Data for Hotazel BIF $(n=5)$ and ores $(n=9)$ taken from Chisonga (2012).

\section{Rare earth element geochemistry}

The Post-Archaean Australian Shale (PAAS) normalized REY patterns of unaltered Palaeoproterozoic BIFs, such as those of the Asbesheuwels Subgroup, Koegas Subgroup, Hotazel Formation and Penge Iron Formation, are well known from literature (e.g. Bau and Dulski, 1996; Pickard, 2003). The BIF patterns typically show heavy REE enrichment with positive europium [Eu] and yttrium [Y] anomalies (Fig. 8A) and no cerium [Ce] anomalies (Fig. 8B), indicative of marine water with a limited hydrothermal component (Dymek and Klein, 1988). Assessing the REY patterns of the iron ores (Fig. 8A) and how they differ from the unaltered BIF, provides insight into the nature of the ore forming fluids.

The supergene ores of the Maremane Dome, in contrast to the Kuruman-Penge BIFs, show light REE enrichment and heavy REE depletion, although the latter occur at similar concentrations to those in the BIF (Fig. 8A). Taking into account that REE immobility during enrichment would lead to an REE concentration upgrade in a residual ore, this could be indicative of the supergene fluids in the Maremane Dome preferentially leaching out heavy REE. The hydrothermal ores show similar REE patterns to the unaltered BIF (Fig. 8A), suggesting immobility of all REE where concentrations are higher than the BIF (e.g. Bovenzeekoebaart and Hotazel ores), or leaching of all REE 


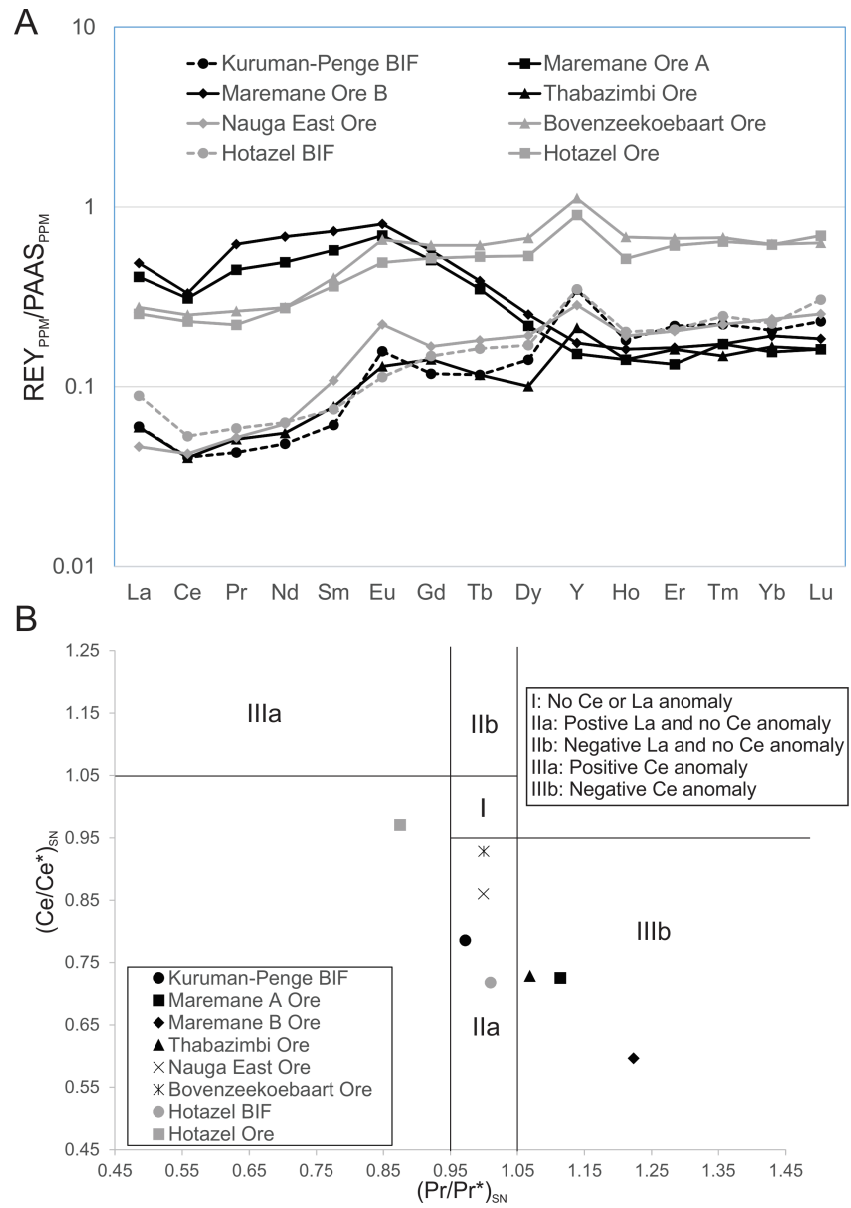

Figure 8: (A) Spider diagrams illustrating the average PAASnormalized REY geochemistries for iron ores and their host BIFS of the Transval Supergroup. (B) Binary plot of the PAASnormalized Ce anomaly versus the PAAS-normalized Pr anomaly after Bau and Dulski (1996). Data for the Kuruman-Penge BIF $(n=25)$, Maremane Dome ores $(n=11$ and $n=16$ for ores $A$ and $B$ respectively), Thabazimbi ores $(n=3)$ and Nauga East ores $(n=3)$ taken from Gutzmer et al. (2008). Data for the Bovenzeekoebaart ores $(n=3)$ taken from Harding (2004). Data for Hotazel BIF $(n=5)$ and ores (n=9) taken from Chisonga (2012). PAAS values obtained from Taylor and McLennan (1988).

where concentrations are similar to the BIF (e.g. Nauga East and Thabazimbi ores).

Ce anomalies are important to take into account as they are indicative of oxidizing conditions (Bau and Dulski, 1996). The unaltered BIF show no $\mathrm{Ce}$ anomalies but rather positive $\mathrm{La}$ anomalies (Fig. 8B). On average this is also the case for the ores at Nauga East, Bovenzeekoebaart and Hotazel. However, the supergene ores of the Maremane Dome, as well as the hydrothermal ore at Thabazimbi, show negative $\mathrm{Ce}$ anomalies indicative of the oxidation of $\mathrm{Ce}$, and therefore oxidative conditions during the ore mineralisation processes.

\section{Oxygen isotope composition of hematite}

Oxygen isotopes of hematite normalized to SMOW, show a range of approximately -3.9 to +3.0 per mil for the supergene BIF-hosted iron ores of the Transvaal Supergroup (Fig. 9). However, the bulk of the values from literature appear to fall between -3 and +1 per mil.
The hydrothermal ores show a SMOW-normalized hematite oxygen isotope range of approximately -6.1 to $+3.4 \%$ with the bulk of the values falling between -6 and -1 per mil (Fig. 9). The hydrothermal ores therefore tend to have more depleted $\delta^{18} \mathrm{O}_{\text {SMOW }}$ values than the supergene ores. Gutzmer et al. (2006) suggest that the ${ }^{18} \mathrm{O}$ depletion of hematite in hydrothermal ores indicates that a fluid of shallow crustal origin, such as brines and meteoric water, enriched the BIF to high grade ores in these deposits. In contrast, ore formation in the supergene deposits did not result in a significant ${ }^{18} \mathrm{O}$ shift from what was present in the unaltered BIF (Gutzmer et al., 2006).

\section{Ore genetic models}

The focus of this section is to review the epigenetic ore-forming processes of the high grade BIF-hosted ores of the Transvaal Supergroup, and not the depositional model of the host BIF. Reviews of older as well as more recent depositional models of pre-great oxidation event supracratonic (i.e. Superior type) BIF, which are applicable to the Transvaal Supergroup BIF, can be found in Klein (2005), Beukes and Gutzmer (2008b), Bekker et al. (2010) and Smith et al. (2013).

\section{Supergene ores}

As noted earlier, high grade BIF-hosted supergene iron ores in the Transvaal Supergroup only occur where the pre-Gamagara unconformity intersects BIF of the Asbesheuwels Subgroup, Koegas Subgroup and Hotazel Formation (Fig. 3A) (Beukes et al., 2003). From this unconformity downwards there is a general, gradual to sharp decrease in ore grades. These, as well as other characteristics (reviewed for the Maremane Dome ore by Van Deventer, 2009), have led to the generally accepted model that the ores were formed due to the leaching of silica from the host BIF during lateritic weathering from the surface (i.e. pre-Gamagara unconformity) downwards (e.g. Van Schalkwyk and Beukes, 1986; Beukes et al., 2003; Carney and Mienie, 2003).

However, though this model is sufficient to explain supergene ore enrichment in the Koegas Subgroup and Hotazel Formation, it is not sufficient to explain the development of the Asbesheuwels Subgroup-hosted large to superlarge deposits encountered in the Maremane Dome.

\section{Large to superlarge supergene ores of the Maremane Dome}

As a result of the numerous stratigraphic, lithological and geochemical similarities between the iron ore deposits of the Maremane Dome, a regional, overarching genetic model will be discussed which is represented in Fig. 10. However, it is important to note that some of the structural history, minor epigenetic processes and post-supergene history, do differ from one deposit to another.

Evidence that supports a supergene ore-forming model for the BIF-hosted iron ore deposits of the Maremane Dome includes the following: the stratigraphic setting of the ores at the top of the Asbesheuwels BIF, below the pre-Gamagara/Mapedi unconformity; palaeomagnetic data from the Beeshoek deposit suggesting that oreformation took place in a near-equatorial climate supporting a lateritic setting (Evans et al., 2002; De Kock et al., 2008); oxygen isotope ranges in ore-forming hematite suggesting normal meteoric water 


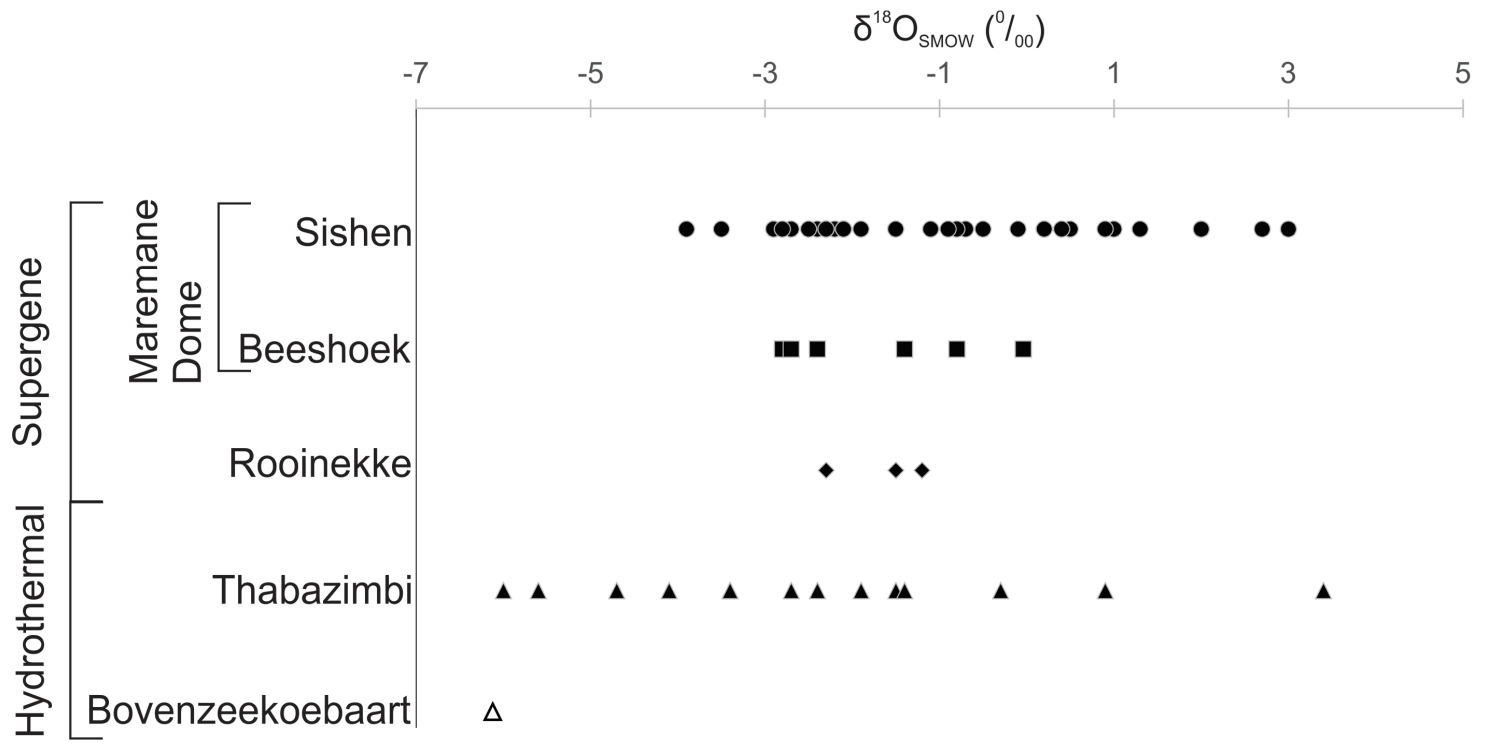

Figure 9: Plot of the $\delta^{18} \mathrm{O}_{\text {SMOW }}$ for hematite from selected BIF-hosted iron ores of the Transvaal Supergroup. Data for Sishen, Rooinekke, Thabazimbi and Bovenzeekoebaart taken from Netshiozwi (2002) and Gutzmer et al. (2006). Data for Beeshoek taken from Van Deventer (2009).

(Gutzmer et al., 2006; Van Deventer, 2009); and heavy REE depletion is observed in the Maremane Dome ores (Gutzmer et al., 2008; Van Deventer, 2009).

The ore-forming fluids that caused the formation of high grade hematite ores had to have been able to do the following: i) dissolve the underlying Campbellrand dolostones as indicated by the presence of the Wolhaarkop chert breccia below ore sections and the occurrence of the ore bodies in palaeokarstic slump structures; ii) oxidize $\mathrm{Fe}^{2+}$ to $\mathrm{Fe}^{3+}$ as indicated by the lack of ferrous minerals and a dominance of hematite in the ore when compared to precursor BIF; iii) dissolve and remove silica as indicated by low silica contents in the ore when compared to precursor BIF; and iv) reprecipitate hematite as suggested by a general lack of visible volume loss in laminated and massive ores. These characteristics led Van Deventer (2009) to propose the following genetic model for the formation of BIF-hosted ore on the Maremane Dome: Initially, acidic circulating meteoric fluids dissolved the Campbellrand dolostones, leading to karst formation (Fig. 10B) and slumping of the Asbesheuwels BIF into the karst structures (Fig. 10C). The carbonate dissolution lead to an increase of the fluid's $\mathrm{pH}$, which then enabled the fluid to start leaching silica (Klemm, 2000) from the BIF, as well as oxidize $\mathrm{Fe}^{2+}$ to $\mathrm{Fe}^{3+}$ leading to the precipitation of hematite and thereby ore formation (Fig. 10D). As a lateritic weathering profile developed above the BIF, descending meteoric fluids would be acidic, leaching iron as $\mathrm{Fe}^{2+}$ from overlying layers and transporting it to lower levels (Fig. 10D). Either due to carbonate dissolution or due to mixing with higher $\mathrm{pH}$ fluids at depth, the acidic fluids will have increased their $\mathrm{pH}$ and allowed the precipitation of hematite which could have replaced the leached silica, limiting the volume loss in the high grade massive and laminated ores. This was followed by erosion, the formation of the pre-Gamagara/ Mapedi unconformity and deposition of the Doornfontein conglomerate and its associated conglomeratic ore (Fig. 10E).

The conglomeratic ore overlies the pre-Gamagara/Mapedi unconformity in the Doornfontein conglomerate at all iron ore deposits (Fig. 4) and is the dominant ore in the south of the Khumani and the north of the Beeshoek deposit. A positive conglomerate test on the hematite pebbles in the conglomeratic ore, which shows random magnetic directions for the different pebbles, indicates that ore enrichment of the pebbles took place before they were deposited in the conglomerate (Evans et al., 2002; De Kock et al., 2008). This suggests that the conglomeratic ores in the Maremane Dome formed as an erosional product of Asbesheuwels Subgroup-hosted massive and laminated ores that were deposited in depressions or basins on the flanks of the Maremane Dome. Some of these depressions or basins occurred above ore and BIF units that had slumped into sinkholes (Fig. 10E). The dome is believed to have had maximum uplift and erosion in its central section, as indicated by surface exposure of the Campbellrand dolostones and a lack of preserved Asbesheuwels Subgroup units in the region. This also explains the dominance of conglomeratic over laminated and massive ores in the southern part of the Khumani deposit, just north of the center of the dome, and the north of the Beeshoek deposit, just south of the center of the dome. It is important to note the role that the formation of karstic structures in the Campbellrand dolostones played, not only in the formation of the BIF-hosted ores but also in the preservation of this ore with regards to pre-Gamagara/Mapedi erosion, as well as in the deposition of conglomeratic ore.

An age range for the main supergene ore-forming event that upgraded the Asbesheuwels Subgroup BIF in the Maremane Dome was obtained through paleomagnetic study and is approximately 2.22 to $2.06 \mathrm{Ga}$ (Evans et al., 2002; De Kock et al., 2008). The results were obtained by measuring the paleomagnetism of hematite pebbles in the Doornfontein conglomerate at Beeshoek and by comparing it to other known Paleoproterozoic poles from the Kaapvaal Craton.

\section{Hydrothermal ores at Thabazimbi}

At the Thabazimbi deposit, the following observations and evidence support a hydrothermal origin for the ore: the occurrence of the tabular ore bodies at the base of the Penge Iron Formation on the contact with the black shales; the presence of hydrothermal sparitic calcite and dolomite within the ore (Netshiozwi, 2002); mineralisation 
A

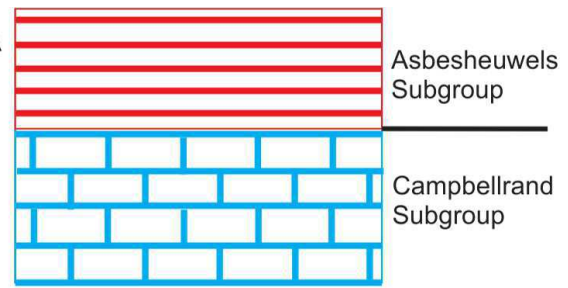

Formation of carbonates and overlying BIF
B

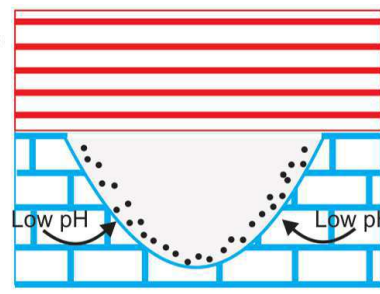

Dissolution/karstification of underlying carbonates

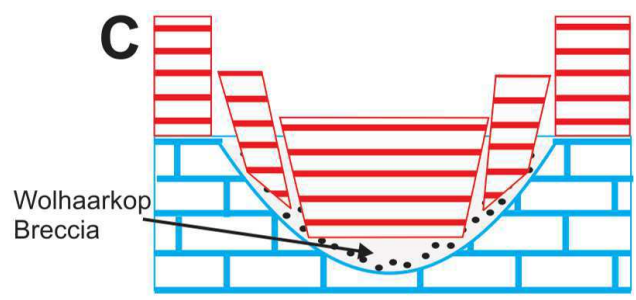

Slumping of BIF into karst structures of the underlying carbonates
D

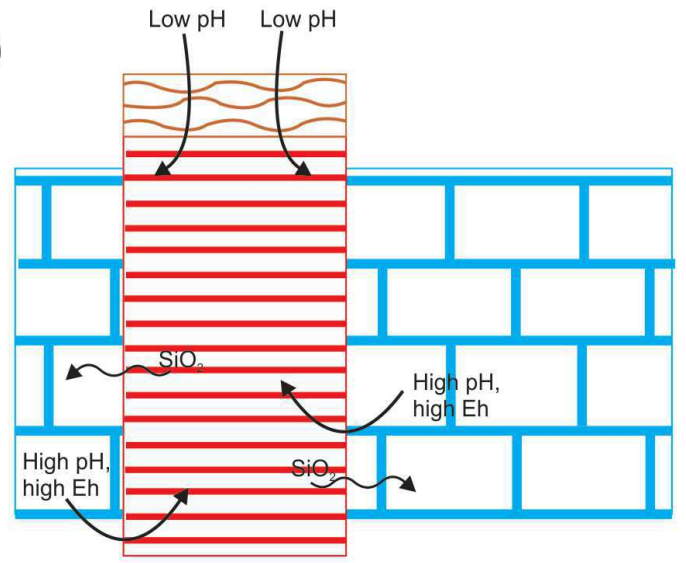

Supergene enrichment of BIF by circulation of meteoric water
$\mathbf{E}$

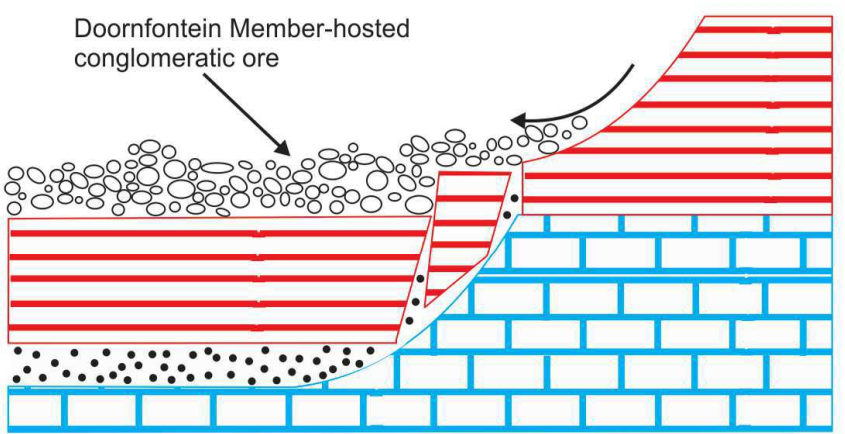

Formation of conglomeratic ore in Doornfontein Member caused by the erosion of higher lying enriched BIF and deposition in low lying areas

Figure 10: Diagram illustrating the genetic model for the formation of the superlarge Maremane Dome-hosted high grade iron ore deposits (adapted from Gutzmer and Beukes, 1996; Van Deventer, 2009).

along low angle normal lystric faults (Fig. 5) that removed stratigraphy along the Penge-Malmani contact (Beukes et al., 2003); fluid inclusions in sparitic calcite and dolomite, suggesting two fluids (see next paragraph) of hydrothermal origin (Netshiozwi, 2002); and a depletion in $\delta^{18} \mathrm{O}$ in ore-forming hematite (Gutzmer et al., 2006; 2008).

Through fluid inclusion studies by Netshiozwi (2002), two hydrothermal fluids have been identified: a high salinity brine; and an intermediate salinity brine thought to be of meteoric origin. Hydrothermal fluids most likely used the normal faults as conduits to cause two stages of hydrothermal alteration, with the first stage believed to have caused the oxidation of all ferrous minerals and their replacement by hematite. This stage affected a much larger volume of rock than just that in the ore zones, as can be seen in a wide halo of oxidized BIF and shale surrounding the ore (Netshiozwi, 2002). The second stage of hydrothermal alteration caused the efficient leaching of chert. The leached chert could have been: replaced by porous microplaty hematite to form high grade hematite ore without significant volume loss (Beukes et al., 2003); replaced by sparitic calcite or dolomite to form carbonate-hematite ore seen at depth (Netshiozwi, 2002); not replaced, leading to compaction and increased porosity (Beukes et al., 2003).

The previously mentioned underlying shales, overlying sill and cross-cutting dykes appear to have exerted a control on the localization of the ore bodies at Thabazimbi (Netshiozwi, 2002; Beukes et al., 2003). In some instances ore bodies are only developed next to dolerite dykes and the most commonly occurring basal ore body type exclusively occurs above the basal shale and below the dolerite sill. The shales and pre-ore formation diabase sill therefore appear to have acted as seals to the hydrothermal fluids due to their low porosity and relative impermeability (Netshiozwi, 2002; Beukes et al., 2003).

Using mineralogical and structural evidence, the timing of ore formation at the Thabazimbi deposit was originally bracketed by Netshiozwi (2002), to be between the intrusion of the Bushveld Complex ( 2060 to $\sim 2055 \mathrm{Ma}$ ) (Scoates et al., 2012) and triplication of the stratigraphy by thrust faulting. The dolerite sill intruding the Penge Iron Formation above the ore bodies predates ore formation (Netshiozwi, 2002; Beukes et al., 2003) and was determined by Chisonga (2012), using titanite, to have an age of approximately 2047 $\mathrm{Ma}$, thus providing a better constrained maximum age of ore formation at Thabazimbi. A further time constraint can be inferred by the presence of iron ore pebbles within the Waterberg Group, over which Transvaal Supergroup strata have been thrust to the north of Thabazimbi (Netshiozwi, 2002). The minimum age of deposition for the Waterberg Group is approximately $1927 \mathrm{Ma}$, as indicated by baddeleyite ages for dolerite sills intruding the succession (Hanson et al., 2004). The ore-forming process at Thabazimbi therefore occurred approximately between 2047 and 1927 Ma, although a minimum age of approximately 1930 Ma was proposed by De Kock et al. (2008) as based upon regional correlations made in the Waterberg Group by Dorland et al. (2006).

\section{Hydrothermal ores at Bovenzeekoebaart}

Similarities between the hydrothermal ores at Bovenzeekoebaart and Thabazimbi include the following: the host BIFs are believed to be time equivalents in the Griqualand West and Transvaal regions; 
occurrence of laminated and massive ore at both deposits; shales underlying both the ore bodies; oxidized BIF overlying the ore bodies; the occurrence of thrust fault systems; faulted contacts between lithological units; and a diabase sill to the west of the ore bodies (i.e. overlying the ore bodies; Harding, 2004). The Bovenzeekoebaart deposit is different from the deposit at Thabazimbi in the following ways: lack of carbonate ore; major folding and overturning of strata; and lack of any crosscutting intrusions (Harding, 2004).

The strong similarities between the Bovenzeekoebaart and Thabazimbi deposits, led Harding (2004) to propose a similar two stage hydrothermal ore-forming process for the former, comprising oxidation of the host BIF followed by leaching and replacement of chert, with the exception that there is no carbonate replacement at Bovenzeekoebaart. Slight supergene alteration occurred in geologically recent times at Bovenzeekoebaart, as indicated by goethite formation in the ores (Harding, 2004). The exclusive occurrence of the ore bodies above shales and below the diabase sill suggests that these exerted a strong control on the localization of the ore bodies by acting as impermeable seals to the hydrothermal fluids, just as inferred for Thabazimbi. No age constraints are available for ore formation at Bovenzeekoebaart.

\section{Magmatically induced hydrothermal ores at the Nauga East Deposit}

At the Nauga East iron ore deposit, the occurrence of the ore bodies, exclusively above the syenite-carbonatite that intruded along the shale-BIF contact, as well as regional oxidation of the Kuruman BIF, led Harding (2004) to conclude that the intrusion of carbonatitic fluid and oxidation, were the main driving forces in the formation of the enriched iron ore.He proposed three stages to ore formation: i) incipient oxidation of the Kuruman BIF and leaching of carbonates with pervasive replacement by hematite; ii) intrusion of the syenite acting as a plug; and iii) intrusion of the carbonatite leading to syenite alteration, dissolution of silica from the BIF and further crystallization of hematite. The hydrothermal ore-forming event at Nauga East was followed by oxidation during supergene weathering, as well as the precipitation of botryoidal hematite. No age constraints are available for ore formation at Nauga East.

\section{Concluding remarks}

South Africa was the seventh largest producer of iron ore in the world at the time of writing (USGS, 2015) and the size and variety of its BIF-hosted high-grade iron ore deposits are of global significance and high economic value. Studies of South Africa's deposits have also led to a better understanding of the geological setting and genesis of these ores that can be applied to other iron ore deposits in the world. Much more scientific research can still be carried out on these deposits, especially with regards to better constraining the timing of events, the structural controls on formation and the nature of the mineralising fluids.

With regard to the outlook of iron ore mining in South Africa, at the end of 2014, the total remaining mineable iron ore reserves for the five largest BIF-hosted iron ore deposits were estimated to be approximately $1.51 \mathrm{Bt}$ (Kumba annual results, 2014; Assore integrated annual report, 2014). Based on mining company projections and current production rates, this places the life of mine for the deposits at approximately between 15 and 20 years, with the exception of
Thabazimbi and Beeshoek, which are likely to be mined out sooner. It therefore appears that iron ore production within South Africa will decrease substantially within the next 20 years unless current deposits are expanded to include deeper and/or lower grade ores, unmined deposits are brought into production, Archaean and Bushveld magnetite ores are exploited or new deposits are found.

\section{Acknowledgements}

The Department of Geology at the University of Johannesburg, the Palaeoproterozoic Mineralisation Research Group (PPM), Kumba Iron Ore and the Department of Science and Technology (DST) and National Research Foundation (NRF) funded Centre of Excellence for Integrated Mineral and Energy Resource Analysis (CIMERA) are thanked for their funding and support. Jens Gutzmer is thanked for his valuable contributions on iron ore research at PPM. The authors would also like to thank the post-graduate students who have investigated the Transvaal Supergroup-hosted iron ores over the last two decades at PPM and whose dissertations and theses greatly contributed to this review. Conrad de Kock and Wikus van Deventer are thanked for providing diagrams and pictures. Marius Burger of Assmang is also thanked for providing information on Beeshoek and Khumani Mines. Pieter Mienie and Ken Liu are thanked for the reviews of this contribution and Mike Wilson for his editing that greatly helped in improving its quality.

\section{References}

Alchin, D.J. and Botha, W.J. (2006). The structural/stratigraphic development of the Sishen South (Welgevonden) iron ore deposit, South Africa, as deduced from ground gravity data modelling. Applied Earth Sciences (Trans. Inst. Min. Metall. B), 115, 174186.

Alchin, D., Lickfold, V., Mienie, P.J., Nel, D. and Strydom, M. (2008). An integrated exploration approach to the Sishen South iron ore deposit, Northern Cape Province, South Africa, and its implication for developing a structural and/or resource model for these deposits. In: Hagemann, S., Rosière, C., Gutzmer, J. and Beukes, N.J. (Eds), Reviews in Economic Geology, Vol. 15, Society of Economic Geologists, Littleton, 317-338.

Assore - Integrated annual report for the year ended 31 December 2014. Available at http://www.assore.com/investor-centre/annualreports-14/.

Bau, M. and Dulski, P. (1996). Distribution of yttrium and rare-earth elements in the Penge and Kuruman iron-formations, Transvaal Supergroup, South Africa. Precambrian Research, 79, 37-55.

Bekker, A., Slack, J.F., Planavsky, N., Krapez, B., Hofmann, A., Konhauser, K.O. and Rouxel, O.J. (2010). Iron formation: The sedimentary product of a complex interplay among mantle, tectonic, oceanic, and biospheric processes. Economic Geology, 105, 467-508.

Beukes, N.J. (1978). The carbonate lithologies and iron formations of the Ghaap Group of the Transvaal Supergroup in the Northern Cape. PhD thesis (unpubl.), Rand Afrikaans University, Johannesburg, 580pp.

Beukes, N.J. and Gutzmer, J. (1998). Earliest laterites and possible evidence for terrestrial vegetation in the Early Proterozoic. Geology, 26, 263-266.

Beukes, N.J. and Gutzmer, J. (2008a). Excursion guide and abstract volume, Workshop on banded iron formation-related high-grade iron ore (unpubl.), June 28 - July 5 2008, Kuruman, 86pp. 
Beukes, N.J. and Gutzmer, J. (2008b). Origin and paleoenvironmental significance of major iron formations at the Archaean-Paleoproterozoic boundary. In: Hagemann, S., Rosière, C., Gutzmer, J. and Beukes, N.J. (Eds), Reviews in Economic Geology, Vol. 15, Society of Economic Geologists, Littleton, 5-47.

Beukes, N.J. and Smit, C.A. (1987). Evidence for thrust faulting in Griqualand West, South Africa: Implications for stratigraphy and the age of the red beds. Transactions of the Geological Society of South Africa, 90, 378-394.

Beukes, N.J., Gutzmer, J. and Mukhopadhyay, J. (2003). The geology and genesis of high-grade iron ore deposits. Applied Earth Sciences (Trans. Inst. Min. Metall. B), 112, B18-B25.

Cairncross, B. and Beukes, N.J. (2013). The Kalahari Manganese Field: The Adventure Continues, Struik Nature, Cape Town, 384pp.

Cairncross, B., Beukes, N.J. and Gutzmer, J. (1997). The Manganese Adventure, Associated Ore and Metal Corporation Limited, Johannesburg, 236pp.

Carney, M.D. and Mienie, P.J. (2003). A geological comparison of the Sishen and Sishen South (Welgevonden) iron ore deposits, Northern Cape Province, South Africa. Applied Earth Sciences (Trans. Inst. Min. Metall. B), 112, B81-B88.

Chisonga, B.C. (2012). Proterozoic mafic dykes and sills associated with BIF-hosted iron ore, South Africa - Implications for the distribution of the Bushveld and Umkondo large igneous provinces. PhD thesis (unpubl.), University of Johannesburg, Johannesburg, 258pp.

Dalstra, H.J. and Rosière, C.A. (2008). Structural controls on highgrade iron ores hosted by banded iron formation: a global perspective. In: Hagemann, S., Rosière, C., Gutzmer, J. and Beukes, N.J. (Eds), Reviews in Economic Geology, Vol. 15, Society of Economic Geologists, Littleton, 73-106.

De Kock, M.O., Evans, D.A.D., Gutzmer, J., Beukes, N.J. and Dorland, H.C. (2008). Origin and timing of banded iron formation-hosted high-grade hematite deposits - a paleomagnetic approach. In: Hagemann, S., Rosière, C., Gutzmer, J. and Beukes, N.J. (Eds), Reviews in Economic Geology, Vol. 15, Society of Economic Geologists, Littleton, 49-71.

Dorland, H.C., Beukes, N.J., Evans, D.A.D. and Armstrong, R.A. (2006). Precise SHRIMP U-Pb zircon age constraints on the lower Waterberg and Soutpansberg Groups, South Africa. South African Journal of Geology, 109, 139-156.

Du Plessis, C.P. (1990). Tectonics along the Thabazimbi-Murchison lineament. PhD thesis (unpubl.), Witwatersrand University, Johannesburg, 307pp.

Dymek, R.F. and Klein, C. (1988). Chemistry, petrology and origin of banded iron-formation lithologies from the $3800 \mathrm{Ma}$ Isua supracrustal belt, West Greenland. Precambrian Research, 39, 247 302.

Eriksson, P.G., Altermann, W. and Hartzer, F.J. (2006). The Transvaal Supergroup and its precursors. In: Johnson, M.R., Anhaeusser, C.R. and Thomas, R.J. (Eds), The Geology of South Africa, Geological Society of South Africa and Council for Geoscience, Johannesburg, 237-260.

Evans, D.A.D., Beukes, N.J. and Kirschvink, J.L. (2002). Paleomagnetism of a lateritic paleoweathering horizon and overlying Paleoproterozoic red beds from South Africa: Implications for the Kaapvaal apparent polar wander path and a confirmation of atmospheric oxygen enrichment. Journal of Geophysical Research, 107, NO. B12, 2326, doi:10.1029/ 2001JB000432.

Grobbelaar, W.S., Burger, M.A., Pretorius, A.I., Marais, W. and Van Niekerk, I.J.M. (1995). Stratigraphic and structural setting of the Griqualand West and the Olifantshoek Sequences at Black Rock,
Beeshoek and Rooinekke Mines, Griqualand West, South Africa. Mineralium Deposita, 30, 152-161.

Gutzmer, J. (1996). Genesis and alteration of the Kalahari and Postmasburg manganese deposits, Griqualand West, South Africa. $\mathrm{PhD}$ thesis (unpubl.), Rand Afrikaans University, Johannesburg, 266pp.

Gutzmer, J. and Beukes, N.J. (1996). Karst-hosted fresh-water Paleoproterozoic manganese deposits, Postmasburg, South Africa. Economic Geology, 91, 1435-1454.

Gutzmer, J. and Beukes, N.J. (1998). Earliest laterites and possible evidence for terrestrial vegetation in the Early Proterozoic. Geology, 26, 263-266.

Gutzmer, J. and Beukes, N.J. (2002). Origin of manganese and iron ores at Rooinekke, Northern Cape Province, South Africa. Project Report (unpubl.), Rand Afrikaans University, Johannesburg, 75pp.

Gutzmer, J., Mukhopadhyay, J., Beukes, N.J., Pack, A., Hayashi, K. and Sharp, Z.D. (2006). Oxygen isotope composition of hematite and genesis of high-grade BIF-hosted iron ores. In: Kesler, S.E. and Ohmoto, H. (Eds), Evolution of Early Earth's Atmosphere, Hydrosphere, and Biosphere - Constraints from Ore Deposits, Geological Society of America Memoir 198, 257-268.

Gutzmer, J., Chisonga, B.C. and Beukes, N.J. (2008). The geochemistry of banded iron formation-hosted high-grade hematite-martite iron ores. In: Hagemann, S., Rosière, C., Gutzmer, J. and Beukes, N.J. (Eds), Reviews in Economic Geology, Vol. 15, Society of Economic Geologists, Littleton, 157183.

Hagemann, S., Rosière, C., Gutzmer, J. and Beukes, N.J. (2008). Introduction: Banded iron formation-related high-grade iron ore. In: Hagemann, S., Rosière, C., Gutzmer, J. and Beukes, N.J. (Eds), Reviews in Economic Geology, Vol. 15, Society of Economic Geologists, Littleton, 1-4.

Hanson, R.E., Gose, W.A., Crowley, J.L., Ramezani, J., Bowring, S.A., Bullen, D.S. and Hall, R.P. (2004). Paleoproterozoic intraplate magmatism and basin development on the Kaapvaal Craton: Age, paleomagnetism and geochemistry of $\sim 1.93$ to $\sim 1.87$ Ga post-Waterberg dolerites. South African Journal of Geology, 107, 233-254.

Harding, C.J. (2004). Origin of the Zeekoebaart and Nauga East highgrade iron ore deposits, Northern Cape Province, South Africa. MSc dissertation (unpubl.), Rand Afrikaans University, Johannesburg, 128pp.

Holland, H.D. and Beukes, N.J. (1990). A paleoweathering profile from Griqualand West, South Africa: Evidence for a dramatic rise in atmospheric oxygen between 2.2 and 1.9 BYBP. American Journal of Science, 290, 1-34.

James, H.L. (1954). Sedimentary facies of iron-formation. Economic Geology, 235-293.

Klein, C. (2005). Some Precambrian banded iron-formations (BIFs) from around the world: Their age, geologic setting, mineralogy, metamorphism, geochemistry, and origin. American Mineralogist, 90, 1473-1499.

Klemm, D.D. (2000). The formation of Palaeoproterozoic banded iron formations and their associated Fe and Mn deposits, with reference to the Griqualand West deposits, South Africa. Journal of African Earth Sciences, 30, 1-24.

Kumba Iron Ore Limited - Summarised annual results for the year ended 31 December 2014. Available at http://www.angloamerican kumba.com/ /media/Files/A/Anglo-American-Kumba/ Annual\%20Reports/2014/.

Nel, B.P. (2013). Petrography and geochemistry of iron formations of the Paleoproterozoic Koegas Subgroup, Transvaal Supergroup, Griqualand West, South Africa. MSc dissertation (unpubl.), University of Johannesburg, Johannesburg, 133pp. 
Netshiozwi, S.T. (2002). Origin of high-grade hematite ores at Thabazimbi Mine, Limpopo Province, South Africa. MSc dissertation (unpubl.), Rand Afrikaans University, Johannesburg, $135 \mathrm{pp}$.

Partridge, T.C., Botha, G.A. and Haddon, I.G. (2006). Cenozoic deposits of the interior. In: Johnson, M.R., Anhaeusser, C.R. and Thomas, R.J. (Eds), The Geology of South Africa, Geological Society of South Africa and Council for Geoscience, Johannesburg, 585-604.

Perry, E.C. and Ahmad, S.N. (1983). Oxygen isotope geochemistry of Proterozoic chemical sediments. In: Medaris, L.G., Byers, L.G., Mickelson, D.M. and Shanks, W.C. (Eds), Proterozoic Geology: Selected papers from an international Proterozoic symposium, Geological Society of America Memoir 161, 253-263.

Pickard, A.L. (2003). SHRIMP U-Pb zircon ages for the Palaeoproterozoic Kuruman Iron Formation, Northern Cape Province, South Africa: evidence for simultaneous BIF deposition on Kaapvaal and Pilbara Cratons. Precambrian Research, 125, 275-315.

Scoates, J.S., Wall, C.J., Friedman, R.M., Van Tongeren, J.A. and

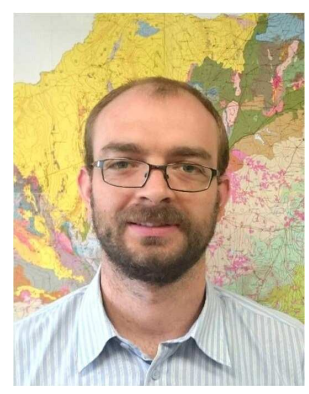

Bertus Smith is a senior lecturer in the Department of Geology at the University of Johannesburg where he has been teaching and researching full-time since 2008. He is also involved as a researcher and student supervisor with the PPM Research Group and the South African Department of Science and Technology - National Research Foundation's Centre of Excellence for Integrated Mineral and Energy Resources Analysis (DST-NRF CIMERA) at the University of Johannesburg. His main research interests are economic geology, early Earth surface palaeoenvironments and process mineralogy.
Mathez, E.A. (2012). Age of the Bushveld Complex. Mineralogical Magazine, 76, 2348.

Smith, A.J.B., Beukes, N.J. and Gutzmer, J. (2013). The composition and depositional environments of Mesoarchaean iron formations of the West Rand Group of the Witwatersrand Supergroup, South Africa. Economic Geology, 108, 111-134.

Trendall, A.F. (1983). Introduction. In: Trendall, A.F. and Blockley (Eds), Iron-formations: Facts and problems, Elserivier, Amsterdam, 1-11.

United States Geological Survey - Mineral Commodity Summaries 2015.

Van Deventer, W.F. (2009). Textural and geochemical evidence for a supergene origin of the Paleoproterozoic high-grade BIF-hosted iron ores of the Maremane Dome, Northern Cape Province, South Africa. MSc dissertation (unpubl.), University of Johannesburg, Johannesburg, 107pp.

Van Schalkwyk, J.F. and Beukes, N.J. (1986). The Sishen iron ore deposit, Griqualand West. In: Anhaeusser, C.R. and Maske, S. (Eds), Mineral Deposits of Southern Africa, Geological Society of South Africa, Johannesburg, 931-956.

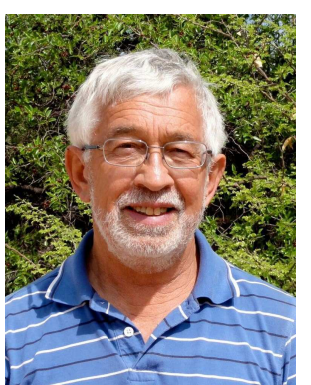

Nicolas J. Beukes is the Research Professor of Geology and Director of the DST-NRF Centre of Excellence for Integrated Mineral and Energy Resource Analysis (CIMERA) at the University of Johannesburg. He is essentially a field geologist with a focus on basin analyses and depositional systems in the Palaeoproterozoic. He has gained international recognition for his research on Neoarchaean carbonate platform deposits and the origin of Precambrian iron formations, BIF-hosted iron ore and sedimentary manganese ore deposits. He is rated an A1 scientist by the South African National Research Foundation, received the Jubilee Medal and Draper Award of the Geological Society of South Africa and is an Honorary Fellow of the Geological Society of America. 